\title{
Changing Arctic snow cover: A review of recent developments and assessment of future needs for observations, modelling, and impacts
}

\author{
Stef Bokhorst $\mathbb{\complement}$, Stine Højlund Pedersen, Ludovic Brucker, Oleg Anisimov, Jarle W. Bjerke, \\ Ross D. Brown, Dorothee Ehrich, Richard L. H. Essery, Achim Heilig, Susanne Ingvander, Cecilia Johansson, \\ Margareta Johansson, Ingibjörg Svala Jónsdóttir, Niila Inga, Kari Luojus, Giovanni Macelloni, \\ Heather Mariash, Donald McLennan, Gunhild Ninis Rosqvist, Atsushi Sato, Hannele Savela, \\ Martin Schneebeli, Aleksandr Sokolov, Sergey A. Sokratov, Silvia Terzago, Dagrun Vikhamar-Schuler, \\ Scott Williamson, Yubao Qiu, Terry V. Callaghan
}

Received: 29 October 2015 / Revised: 3 November 2015/ Accepted: 5 February 2016/Published online: 17 March 2016

\begin{abstract}
Snow is a critically important and rapidly changing feature of the Arctic. However, snow-cover and snowpack conditions change through time pose challenges for measuring and prediction of snow. Plausible scenarios of how Arctic snow cover will respond to changing Arctic climate are important for impact assessments and adaptation strategies. Although much progress has been made in understanding and predicting snow-cover changes and their multiple consequences, many uncertainties remain. In this paper, we review advances in snow monitoring and modelling, and the impact of snow changes on ecosystems and society in Arctic regions. Interdisciplinary activities are required to resolve the current limitations on measuring and modelling snow characteristics through the cold season and at different spatial scales to assure human well-being, economic stability, and improve the ability to predict manage and adapt to natural hazards in the Arctic region.
\end{abstract}

Keywords Climate change - Ecosystem services . Human health - Societal costs · Indigenous - Snow

\section{INTRODUCTION}

Snow is a critically important element of the Arctic and is rapidly changing due to climate warming (Callaghan et al. 2011). Snow cover, stratigraphy, and physical characteristics are naturally changing throughout the

Electronic supplementary material The online version of this article (doi:10.1007/s13280-016-0770-0) contains supplementary material, which is available to authorized users. seasons but are likely to be affected by climate warming with unexpected impacts for ecosystems and society. For example, Arctic snow-cover duration is decreasing rapidly ( $\sim 3-5$ days/decade), particularly due to earlier spring melt (20\%/decade) and later onset of snow cover (Derksen et al. 2015). However, the Eurasian Arctic region has experienced larger declines in the duration of the snow-covered period (12.6 days), i.e. prolonged vegetation growing season, compared to the North American Arctic region (6.2 days) between 1982 and 2011 (Barichivich et al. 2013). In addition, climate warming increases the potential for unseasonal thaws, early snowmelt, and rain-on-snow events (ROS) (Liston and Hiemstra 2011). These changes impact snow properties and runoff (Semmens et al. 2013), which in turn affect Arctic ecosystems and societies (Meltofte 2013; Cooper 2014; Hansen et al. 2014). However, changes in snow properties are not uniform across the Arctic and affected processes operate/respond at different temporal and spatial scales. Moreover, the various disciplines working on snow measure and evaluate its properties at different temporal and spatial scales. Therefore, there are potential mismatches on the availability and requirements of snow data between snow scientists, modellers, ecologists, and sociologists.

To address these issues, an interdisciplinary workshop was held to develop a road map to improve measurement, modelling, and prediction of changing snow characteristics and to collate developments in the field since the "Snow Water Ice and Permafrost in the Arctic" assessment of 2011(Callaghan et al. 2011). This paper builds on the results presented at the workshop and presents an overview of recent developments in studies of changing Arctic snow cover and its consequences. 


\section{UNDERSTANDING THE IMPACTS OF CHANGING SNOW CONDITIONS ON SOCIETIES AND ECOSYSTEMS}

\section{Economy, human health, and well-being}

The direct impact of snow temporal and spatial variability on economic development of the Arctic has to our knowledge not been comprehensively evaluated and quantified. Such a study would need to take into account among others: Snow clearing costs of transportation routes (Hanbali 1994; Riehm and Nordin 2012) (Fig. 1), which varies annually and is complicated by extreme snowfalls (Borzenkova and Shmakin 2012). The prevention of freezing damage to water pipes and drainage systems (Bjerke et al. 2015). Associated risks to winter-crops and forestry production due to changes in snow-season duration (Hanewinkel et al. 2011; Krenke et al. 2012), increased frequency of desiccation, exposure to snow moulds (Matsumoto and Hoshino 2009), and encasement in ground ice (Bjerke et al. 2014, 2015). Furthermore, ice-based construction procedures relying on firn-ice (e.g. winter roads) can be affected (Sosnovsky et al. 2014). Seasonal snow conditions are crucial for the way of life of indigenous people and local residents for reindeer herding practices and access to hunting grounds (Riseth et al. 2011), harvest yields of cultivated and wild berries (Bokhorst et al. 2011; Niemi and Ahlstedt 2012), and game animals (Stien et al. 2012; Hansen et al. 2013). Snow-season duration and snow-cover depth also affect the economy through changes in the magnitude and timing of spring runoff and floods. In Siberia, the frequency of dangerous river ice jams and spring river flooding events are increasing (Popova 2011; Semenov 2013), while decreased snow precipitation will affect the water supply for aquatic ecosystems, forestry, and agriculture (Jeelani et al. 2012; Clarke et al. 2015).

The increasingly wetter and milder Arctic climate can lead to increased frequency of avalanches threatening growing populations and infrastructure (Eckerstorfer and Christiansen 2012; Qiu 2014). When comparing snow avalanche risk assessments between regions, losses are often associated with an increase in land use, population density, and economic activities (Shnyparkov et al. 2012). Healthcare costs can rise due to increasing occurrence of bone fractures resulting from unusual snow and ice conditions (Bjerke et al. 2015). Snow can also become a health issue when supporting biological pathogens (Biedunkiewicz and Ejdys 2011; Shen and Yao 2013; Simon et al. 2013; Ejdys et al. 2014). The impacts of changing snowmelt dynamics on snow-pathogens for humans, livestock, and agriculture are unclear (Parham et al. 2015).

\section{Ecosystems}

Snow cover is an important determinant of community and ecosystem structure in polar regions (AMAP 2011) and winter temperatures are increasing in the Arctic more than those during summer (Walsh 2014). However, impacts of changing winter climate and snow regimes have received much less attention compared to the effects of climate change during summer. Different aspects of the snowpack play crucial roles in ecosystem processes and the life of Arctic organisms (e.g. Cooper 2014). Relevant snowpack characteristics include thermal insulation, snow depth, microstructure, temporal changes of these aspects, as well as snow-cover duration, all of which have been shown to be affected by climate change, with important consequences for Arctic ecosystems (AMAP 2011).
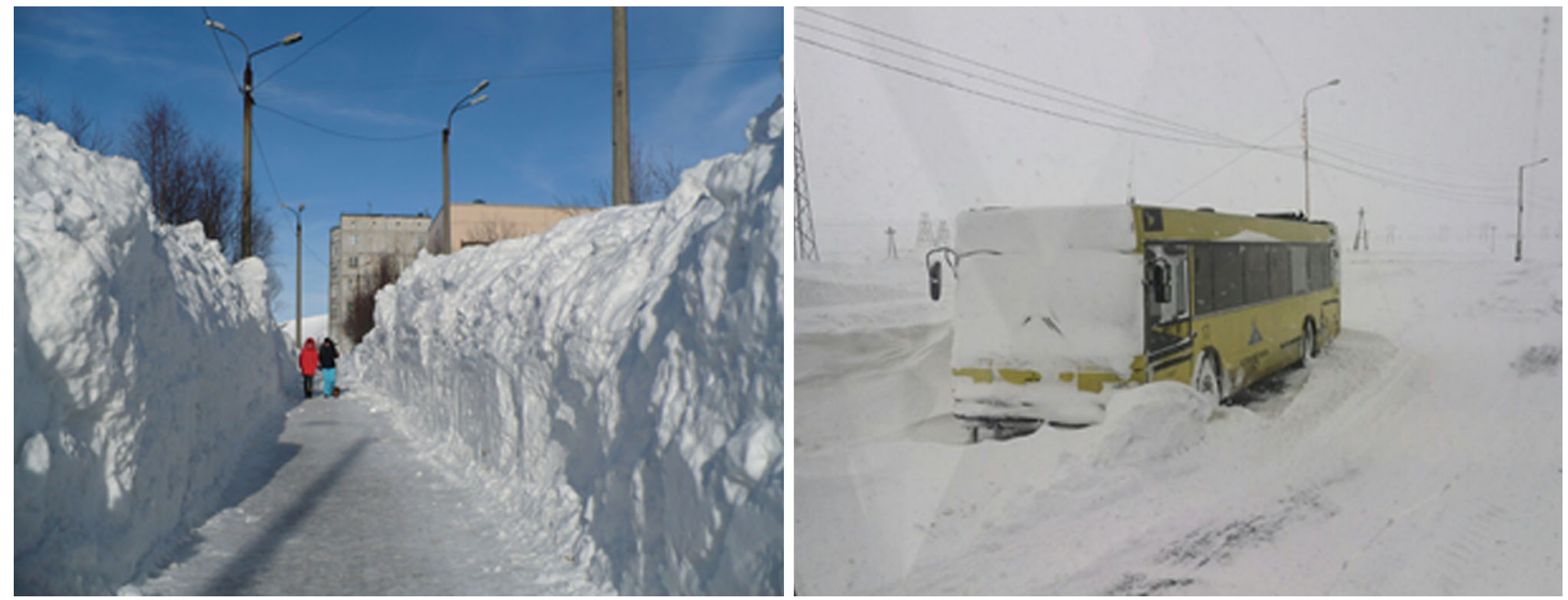

Fig. 1 Increases in heavy snowfall affect the function of cities above the Arctic Circle. Snow clearance (left) has economic costs, whereas lack of snow clearance (right) can perhaps have even greater costs (left Kirovsk and right Norilsk: photos M.N. Ivanov) 


\section{Terrestrial ecosystems}

Snow acts as an insulating blanket against freezing Arctic temperatures for many organisms. Snow is also a major determinant of the mosaic of ecological communities through its uneven landscape distribution and the influence of snowmelt-driven spring flooding on wetland communities. Changes in snow quantity, quality, and seasonality can, therefore, result in changes in the distribution and composition of Arctic communities with resulting effects on their many inherent ecological processes, functions, and feedbacks. Extreme weather events (unseasonal warm temperatures and ROS see Fig. 2) can cause complete loss of snow cover, changes in the snow stratigraphy, snow hardness, and formation of ice layers with great impacts on plants (Bokhorst et al. 2011; Preece et al. 2012), herbivores (Bartsch et al. 2010; Ims et al. 2011; Stien et al. 2012; Bilodeau et al. 2013), soil organisms and $\mathrm{CO}_{2}$ fluxes (Bokhorst et al. 2012, 2013), and agriculture (Bjerke et al. 2014, 2015). However, species responses to extreme weather events and snowmelt are dependent on the timing of events (Bokhorst et al. 2010, 2011), while the mechanisms behind species responses are unclear (Rumpf et al. 2014; Bowden et al. 2015) and processes are often inferred based on indirect correlative information (e.g. Ims et al. 2011). Furthermore, changing snow conditions can have wide-ranging indirect effects mediated by ecological interactions. For instance, shrub growth affects snow accumulation which in turn influences soil temperatures and ecosystem process rates (Myers-Smith and Hik 2013) highlighting the importance of interactions between vegetation structure and snow properties. Snow-induced changes in mortality and dynamics of reindeer and lemming (Hansen et al. 2013) affect predator populations (Schmidt et al. 2012) which in turn may shift to alternative prey (McKinnon et al. 2013; Nolet et al. 2013). These examples highlight the need to identify critical periods when species and ecosystems are vulnerable to winter climate change, especially with regard to periods of snowpack build-up, ROS and ground icing, and spring snowmelt.

Aside from the species-specific and ecosystem responses to changing snow conditions, there is a major research challenge in linking the predictions of snow changes to the scales that are relevant for the organisms or ecosystem that is being studied (Table 1). Specifically, there is a need for accurate predictions of the build-up and change in the snow stratigraphy across scales of a few square metres to landscapes covering several $\mathrm{km}^{2}$.

\section{Freshwater systems}

Snow on lake and river ice affects the temperature and light transmission to the underlying ice and water. Changes in the snowpack can therefore affect the freezing regime, having consequences for the freshwater ecosystem with feedbacks to habitat structure, food availability, and survival of species (Prowse and Brown 2010; Prowse et al. 2011; Surdu et al. 2014). For shallow waters $(<3 \mathrm{~m})$ and wetlands, the timing and duration of ice defines the open water, productive period and limits the active state of aquatic organisms by freezing to the bottom. Winter-dormancy allows species to survive such frozen conditions but the breaking of winterdormancy depends on the photoperiod and temperature (Dupuis and Hann 2009) which is affected by the snow cover. Particularly the formation of 'white ice', formed when the snowpack exceeds the buoyance of the ice, affects the light transfer to the water column below (Dibike et al. 2012). Changing snow conditions affecting freshwater freezing and melting conditions may cause mismatches for organisms in terms of when winter-dormancy ends compared to peak food availability. Ecosystem phenology associated with ice and snow cover in freshwater systems is an area that needs more research.

Spring snowmelt is also an important conduit for transporting organic matter from the land into rivers and lakes. This pulse of organic matter into freshwater affects the clarity (light attenuation), nutrient and carbon cycling, primary productivity, and overall food web dynamics of aquatic ecosystems (Ask et al. 2009; Rautio et al. 2011). Furthermore, dissolved and suspended concentrations of metals are highest in rivers and lakes during the spring freshet (Holemann et al. 2005) indicating that the snowpack acts as a reservoir for contaminants that are released as a pulse (Douglas et al. 2012). The timing of mercury (Hg) runoff, for example, is greatly affected by the spatial variability in hillslope flow paths and the magnitude of snowmelt inputs (Haynes and Mitchell 2012) indicating that predictions of mercury runoff in water streams need to be developed at small scales and that up-scaling will be challenging.

\section{Sea ice and snow}

Variations in snow-covered sea ice affect the Earth's climate by affecting ocean-atmosphere interactions. Snow cover on top of sea ice has a high albedo that dominates the surface solar energy exchange, and a changing thermal conductivity that regulates ice/atmosphere heat transfer that greatly modifies the sea ice thermodynamic processes. The snow cover also modifies surface roughness with implications for the ice/air drag coefficient and sensible and latent heat fluxes. Snow depth and snow properties (e.g. thermal conductivity and density) on sea ice are thus of crucial importance, and must be accurately retrieved on a large scale.

Snow across sea ice influences algal communities with thin snow cover promoting productivity in the ocean 

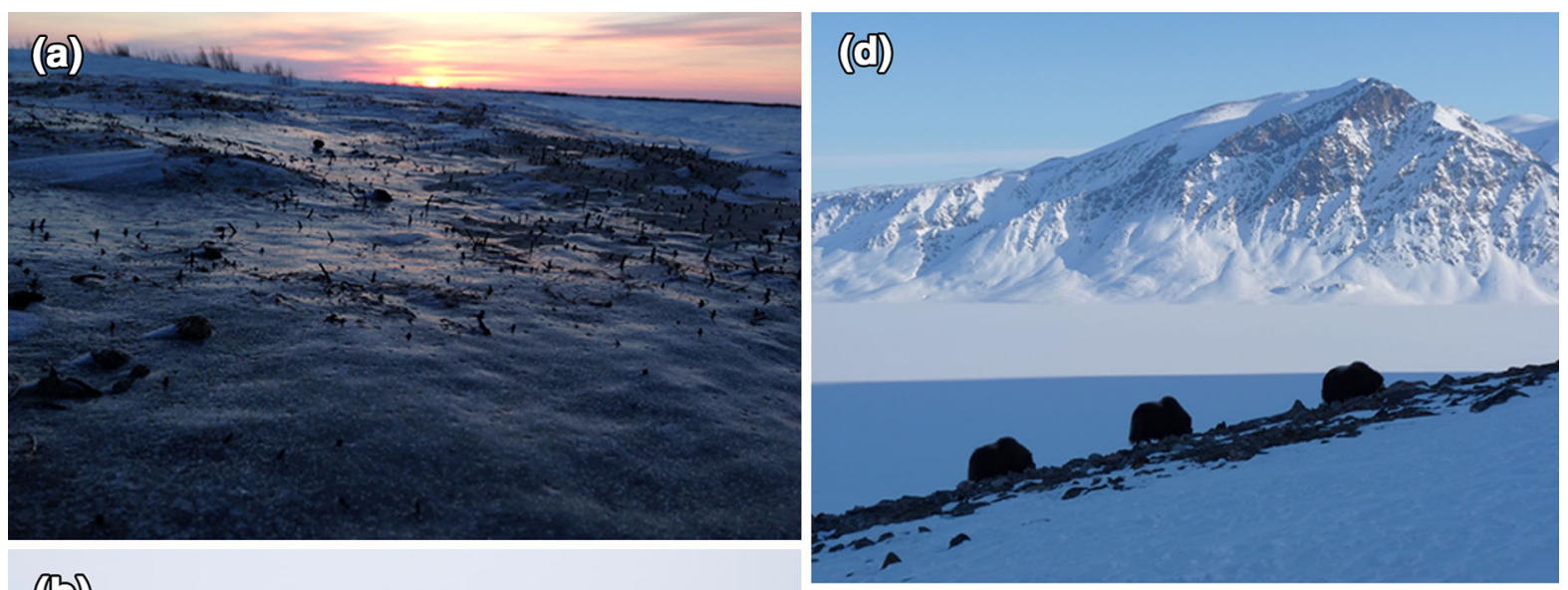

(Bb)
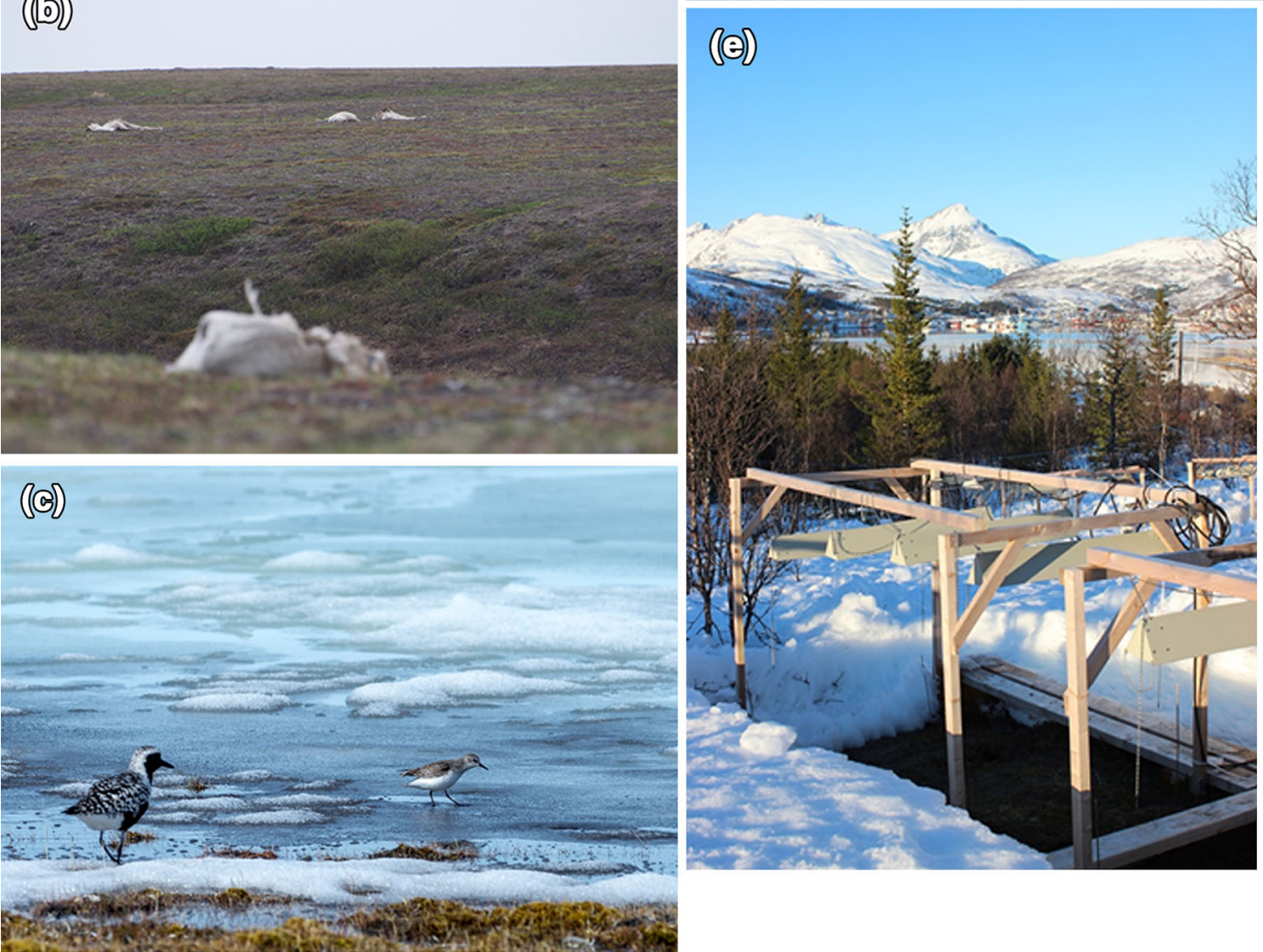

Fig. 2 Examples of changing snow conditions in terrestrial ecosystems: a Vegetation captured in ice layer following rain-on-snow event leading to b mortality among reindeer (Yamal Russia) and c delayed breeding of Black-bellied Plover (Pluvialis squatarola) (Southampton Island, Nunavut, Canada); d Muskoxen (Ovibos moschatus) grazing at high elevation to find snow-free patches during spring 2012, Zackenberg in Northeast Greenland; e Experimental simulation of extreme winter warming near Troms $\emptyset$ (Norway). Photos a and b Aleksandr Sokolov, c K. Young, d S. Højlund Pedersen, and e S. Bokhorst

(Alou-Font et al. 2013). This suggests that reduced snow precipitation or quicker melt out may promote higher primary production underneath sea ice with potential positive impacts higher up the food chain. Conversely, snow-cover removal from the sea ice surface can inhibit spring growth of Arctic ice algae through physiological and behavioural effects (Lund-Hansen et al. 2014).

\section{Teleconnections and snow cover in Arctic amplification}

Research has been dedicated to investigate the linkages between the changing Arctic snow cover and tropospheric processes (Cohen et al. 2014) and the impacts of Arctic amplification to temperature variability at low and high 
Table 1 Overview of the various expected changes in snow conditions, affected groups of organisms, processes, or activities and the modelling requirements that are required to predict their occurrence in the near future. The different affected groups, processes, and/or activities have different spatial and temporal extent and resolution; hence models are required to resolve these specific spatial and temporal dimensions

\begin{tabular}{|c|c|c|c|}
\hline $\begin{array}{l}\text { Changes in climate } \\
\text { and snow }\end{array}$ & Affected groups/processes & Modelling requirements to predict these changes & Scale \\
\hline $\begin{array}{l}\text { Temperature } \\
\text { variability under } \\
\text { the snow (snow } \\
\text { insulation) }\end{array}$ & $\begin{array}{l}\text { Soil organisms, dwarf shrubs, cryptogams } \\
\text { Ecosystem } \mathrm{CO}_{2} \text { fluxes } \\
\text { Shrubs and trees }\end{array}$ & $\begin{array}{l}\text { Snow depth, snow density, snow type, stratigraphy, } \\
\text { and temporal evolution of these through the cold } \\
\text { season }\end{array}$ & $\begin{array}{l}0-1 \mathrm{~m}^{2} \\
0-1 \mathrm{~m}^{2} \\
1-10 \mathrm{~m}^{2}\end{array}$ \\
\hline Ice-layer formation & $\begin{array}{l}\text { Humans, sub-Arctic agroecosystems, vegetation, } \\
\text { small rodents, reindeer, and species depending on } \\
\text { them through direct or indirect trophic interactions }\end{array}$ & $\begin{array}{l}\text { Timing, duration/longevity, compactness, and spread } \\
\text { of (ground) ice formation across the landscape, in } \\
\text { urban areas, and on transportation infrastructure } \\
\text { (roads, airports, culverts) }\end{array}$ & $\begin{array}{l}1-10 \mathrm{~m}^{2} \\
\text { and } \\
>\mathrm{km}^{2}\end{array}$ \\
\hline Avalanche risk & $\begin{array}{l}\text { Society, infrastructure, large grazers, and } \\
\text { mountainside vegetation, especially trees }\end{array}$ & Snow stratigraphy/stability through the cold season & $100 \mathrm{~m}^{2}$ \\
\hline Snow accumulation & $\begin{array}{l}\text { Infrastructure/society, water supply, large grazers and } \\
\text { flooding risk }\end{array}$ & $\begin{array}{l}\text { Snow depth, snow water equivalent, timing of heavy } \\
\text { snowfall events, and snow (re-)distribution by wind }\end{array}$ & $<100 \mathrm{~m}^{2}$ \\
\hline $\begin{array}{l}\text { Snow-cover duration } \\
\text { and timing }\end{array}$ & $\begin{array}{l}\text { Agriculture, freshwater ecosystems, terrestrial } \\
\text { ecosystems, energy use, northern food security, } \\
\text { transportation, and recreation }\end{array}$ & $\begin{array}{l}\text { Snow depth, timing of snow deposition and } \\
\text { snowmelt, and resultant sea ice melt out }\end{array}$ & $<100 \mathrm{~m}^{2}$ \\
\hline
\end{tabular}

latitudes (Francis and Vavrus 2012; Screen 2014). Declining terrestrial spring snow cover in the Arctic is contributing to Arctic amplification (Serreze and Barry 2011; Matsumura et al. 2014). Changing snow on freshwater systems affect local climate conditions (Rouse et al. 2008; Brown and Duguay 2010). Observations of Arctic sea ice reduction in autumn are shown to be causing cold extremes (e.g. additional snowfall) in mid-altitude and northern continents/sub-Arctic areas (Cohen et al. 2013; Tang et al. 2013). Arctic amplification depends on heattransport from lower latitudes but local factors on surface warming is still a matter of debate because it is difficult to isolate local forcings from simultaneously occurring external forcings and feedbacks (Screen and Simmonds 2012). Furthermore, high-latitude responses in the multiple types of forcing between models were broad, making it difficult to define the particular causes of Arctic temperature amplification (Crook et al. 2011). Improved process understanding, additional Arctic observations, and further modelling efforts in collaboration with observation data are required to elucidate the teleconnections with the Arctic (Cohen et al. 2014).

\section{OBSERVATIONS OF CHANGING SNOW CONDITIONS}

Quantifying snow-cover extent, thickness, and specific snow characteristics in the Arctic is challenging mainly due to the inclement weather conditions, polar night, and redistribution of snow by wind. In addition, the limited Arctic snow-observation stations challenge the up-scaling process to larger regions. However, there is a great need for accurate snow data at different spatial and temporal resolutions to address the challenges of changing snow conditions. We present an overview of recent advances in methods for quantifying and monitoring snow variables, and a summary of widely used ground-based snow observational methods is presented in Table 2 . In addition, we indicate data/knowledge gaps where progress is required in terms of spatial and temporal resolution of snow variables.

\section{Overview of recent advances in methods and findings in Arctic snow monitoring}

\section{Ground-based snow-depth monitoring}

Several well-known methods for measuring snow depth exist (Table 2). Recent developments in snow-depth measurements include remote sensing methods that enable an objective monitoring of spatial distributions of snow depth. These methods include polarimetric phase differences (Leinss et al. 2014), ground-based laser scans (Deems et al. 2013), and electromagnetic wave technology (e.g. Koch et al. 2014; McCreight et al. 2014).

\section{Spaceborne snow-cover monitoring}

Snow-cover has high spatial and temporal variability and satellites provide observations at the hemispherical scale. Both passive and active remote sensing methods are used with sensors operating in the visible and microwave domains. Visible sensors observe snow-surface properties (with solar illumination, in cloud-free conditions), and are used for mapping snow-cover extent (e.g. Hall et al. 2002, 2006). Microwave sensors are sensitive to snow properties, 
Table 2 Overview of observation methods in quantifying various snow parameters

\begin{tabular}{|c|c|c|}
\hline Target parameter(s) & Method(s) & Reference(s) \\
\hline & Destructive ground-based snow observations & \\
\hline Snow depth & $\begin{array}{l}\text { Simple (avalanche) or semi-automated probes (e.g. } \\
\text { MagnaProbe) }\end{array}$ & e.g. Sturm et al. (2006) \\
\hline $\begin{array}{l}\text { Specific surface area (SSA) (i.e. } \\
\text { the surface area of ice per unit } \\
\text { mass) }\end{array}$ & $\begin{array}{l}\text { Near-infrared photography and infrared reflectance } \\
\text { methods }\end{array}$ & $\begin{array}{l}\text { e.g. Matzl and Schneebeli (2006), Gallet et al. } \\
\text { (2009) Arnaud et al. (2011), and Montpetit } \\
\text { et al. (2012) }\end{array}$ \\
\hline $\begin{array}{l}\text { Penetration resistance and } \\
\text { deviation of snow density, } \\
\text { grain parameters, and SSA. }\end{array}$ & $\begin{array}{l}\text { SnowMicroPen (Highly resolved measurements ( } 250 \\
\text { measurements } / \mathrm{mm})\end{array}$ & $\begin{array}{l}\text { Schneebeli and Johnson (1998) and Proksch } \\
\text { et al. (2015) }\end{array}$ \\
\hline Snowfall/new snow & $\begin{array}{l}\text { Snow board (i.e. new-snow observations are being } \\
\text { conducted by placing a board (snow board) on the snow } \\
\text { surface and revisiting it every } 24 \mathrm{~h} \text { to read the additional } \\
\text { snow height }\end{array}$ & e.g. Fierz et al. (2009) \\
\hline \multirow[t]{2}{*}{ Liquid water content in snow } & $\begin{array}{l}\text { 'Denoth capacity probe' or 'Finnish Snow Fork' (e.g. } \\
\text { used to deriving dielectric/conduction properties of the } \\
\text { snow) }\end{array}$ & \multirow[t]{3}{*}{ Denoth (1994) and Sihvola and Tiuri (1986) } \\
\hline & Non-destructive ground-based snow observations & \\
\hline Snow depth & $\begin{array}{l}\text { Acoustic snow-depth sensors, ultrasonic methods, lasers, } \\
\text { manual readings at stakes, and automatic readings } \\
\text { utilizing time-lapse cameras }\end{array}$ & \\
\hline \multirow{3}{*}{$\begin{array}{l}\text { Snow density and snow bulk } \\
\text { liquid water content }\end{array}$} & Upward-looking ground penetrating radar (upGPR) & \multirow{4}{*}{$\begin{array}{l}\text { e.g. Mitterer et al. (2011), Avanzi et al. (2014), } \\
\text { Heilig et al. (2015), Schmid et al. (2014, } \\
\text { 2015), and Stacheder (2005) }\end{array}$} \\
\hline & $\begin{array}{l}\text { Combination of upGPR with buried GPS sensors (allows } \\
\text { for direct conversion for density, SWE and liquid water } \\
\text { content) }\end{array}$ & \\
\hline & Time domain reflectometer (TDR) & \\
\hline Snow water equivalent (SWE) & $\begin{array}{l}\text { Snow pillows or snow scales weigh the mass of the } \\
\text { snowpack above the sensors and convert this to SWE }\end{array}$ & \\
\hline Snow albedo & Net radiometer & e.g. Michel et al. (2008) \\
\hline Snow-cover fraction & $\begin{array}{l}\text { Derived from hourly-daily digital photos acquired from } \\
\text { automatic time-lapse digital cameras installed in } \\
\text { terrestrial areas, e.g. near glaciers and ice fields }\end{array}$ & e.g. Bernard et al. (2013) \\
\hline \multirow[t]{2}{*}{ Avalanche hazard and activity } & Seismic sensor & Reiweger et al. (2015) \\
\hline & Infrasound arrays & $\begin{array}{l}\text { e.g. Van Herwijnen and Schweizer (2011), } \\
\text { Havens et al. (2014) }\end{array}$ \\
\hline
\end{tabular}

and operate independently from solar illumination with a weak sensitivity to the atmosphere. The main limitation of using microwave radiometers is the coarse resolution (i.e. tens of kilometres), whereas radars lack the appropriate frequencies. Existing radar sensors, which can provide information on snow-cover with fine resolution, are able to work only in the presence of wet snow.

\section{Snow water equivalent (SWE)}

Satellite algorithms have been developed to monitor SWE at the hemispherical scale since the 1980s (e.g. Kelly 2009). In the early 2000s, surface-based Frequency-Modulated Continuous-Wave (FMCW) radar measurements were used to estimate SWE to within $5 \%$ (Marshall et al. 2005). Furthermore, fixed radars installed underneath or above the snow cover have been used for deriving snow depth, density, bulk liquid water content, and for deriving SWE (Heilig et al. 2009; Schmid et al. 2014) and allow monitoring of the temporal evolution of the overlying snow. In addition, recent advances in SWE quantification have shown the benefit of combining passive microwave radiometer and ground-based synoptic weather station observations to provide robust information on hemispherical scale (Takala et al. 2011). Mobile measurements allow for monitoring spatial differences in SWE or liquid water content but only provide snapshots in time. Hence, there are major challenges to compare satellite-derived information with ground-based in situ data. In addition, further development on sensors for satellites and aircrafts is necessary including new technologies for data interpretation together with up-scaling methods for temporal continuous 
point measurements. Further investigations are required to convert satellite observations into accurate SWE retrievals and remote sensing of SWE is currently restricted to flat areas thereby excluding mountains.

\section{Snow microstructure (grain size, snow-specific surface} area) and liquid water content (LWC)

Snow microstructure is complex, but can be characterized by snow-specific surface area (SSA). SSA controls the snow albedo and is a more objective measure of snow's complexity than grain size. SSA typically decreases with time with a rate depending on temperature and the shape of the initial snow grain (Hachikubo et al. 2014). SSA measurements have been successfully conducted in the field using near IR methods (Gallet et al. 2009; Arnaud et al. 2011; Montpetit et al. 2012). The SnowMicroPen, which uses highly resolved penetration resistance (250 measurements/mm), can be used to quantify snow density, grain size, and SSA (Proksch et al. 2015). Time-lapse X-ray micro-tomography methods provide a $3 \mathrm{D}$ reconstruction of the snow structure (Pinzer et al. 2012) and enable visualization of the recrystallization distribution on depth hoar crystals through time (Fig. 3). Recent development of SSA measurements led to implementation of SSA parametrizations in snow evolution modelling (Carmagnola et al. 2014). Advances in thermal and short IR remote sensing allow for determining surface snow types and surface temperature (Hori et al. 2014).

In snow hydrology, the onset and the total amount of runoff are essential for flood and reservoir management, and impact on terrestrial ecosystems. The change in dielectric permittivity of snow during melt highly influences remote sensing data from microwave to infrared, allowing us to monitor the extent of surficial melt (e.g. Steffen et al. 2004). Modelling of LWC and snowpack runoff is still very challenging and water transport schemes like a multi-layer bucket model or Richards equation underestimate observed maximum LWC in the course of a season (Heilig et al. 2015). LWC retention in the snow is important to improve modelled runoff performance (Essery et al. 2013; Heilig et al. 2015).

\section{Snow-surface albedo and light-absorbing impurities}

Impurities in the snowpack can affect the snowmelt rates through decreased surface albedo. Such light-absorbing snow impurities include organic carbon, mineral dust, and micro-organisms (Langford et al. 2010), and can be quantified in manually collected snow samples and by reflectance measurements. Algal communities have been associated with glacial melt and reducing snow-surface albedo (e.g. Tedesco et al. 2013; Lutz et al. 2014). Similar responses to deposits of black carbon (BC) on the snow surface are shown to cause accelerating snowmelt rates in Alaska, Norway, and Greenland (Doherty et al. 2013). Particle size of snow impurities can be used to identify their source and have been linked to peripheral snow-free areas or locations with early snowmelt and fires (Aoki et al. 2014; Dumont et al. 2014). A decreasing snow-cover extent may play a major role in the surface mass balance of Arctic ice bodies.

Snow on sea, lake, and river ice

Snow cover on sea ice influences the Earth's climate and biology in the ocean. The only current snow-depth-on-seaice algorithm that uses satellite data is based on passive microwave observations (Cavalieri et al. 2012; Brucker and Markus 2013). Since 2009, NASA has supported the airborne Operation IceBridge mission, which operates multiple radars to retrieve snow depth on sea ice (Kurtz et al. 2013; Panzer et al. 2013). Recent work on IceBridge data and from drifting ice station indicates a substantial thinning of the snowpack in the western Arctic and in the Beaufort and Chukchi seas (Webster et al. 2014). This thinning is negatively correlated with the delayed onset of sea-ice freeze-up during autumn. Thin snowpack and sea ice increase the heat flux between the ocean and atmosphere with potential feedbacks for the Earths' climate but are not thoroughly investigated. Although snow on lake ice has major implications for lake ecology, ice thickness, and the local climate (Brown and Duguay 2010), studies on these systems appear to be under-represented in the literature (Cheng et al. 2014; Duguay et al. 2015). Furthermore, there is currently little focus on quantifying changes in lake-ice snow cover. The most recent progress in remote sensing is summarized in Duguay et al. (2015).

\section{Avalanche detection}

Recent advances in avalanche detection include the use of seismic sensors and infrasound arrays (Table 2). Furthermore, Synthetic Aperture Radar (SAR), e.g. Radarsat-2, TerraSAR-X, and Cosmo-Skymed, have been shown useful in detecting avalanche activity. Especially, the SAR data properties as the spatial resolution (2-3 m), high temporal resolution (2-5 days), and their application during cloudy conditions make them ideal for this purpose (Caduff et al. 2015).

\section{Indigenous knowledge: Sámi snow observational methods and terminology}

Snow plays a central role in the cultures of indigenous Arctic people, notably for the reindeer herders of Eurasia. 


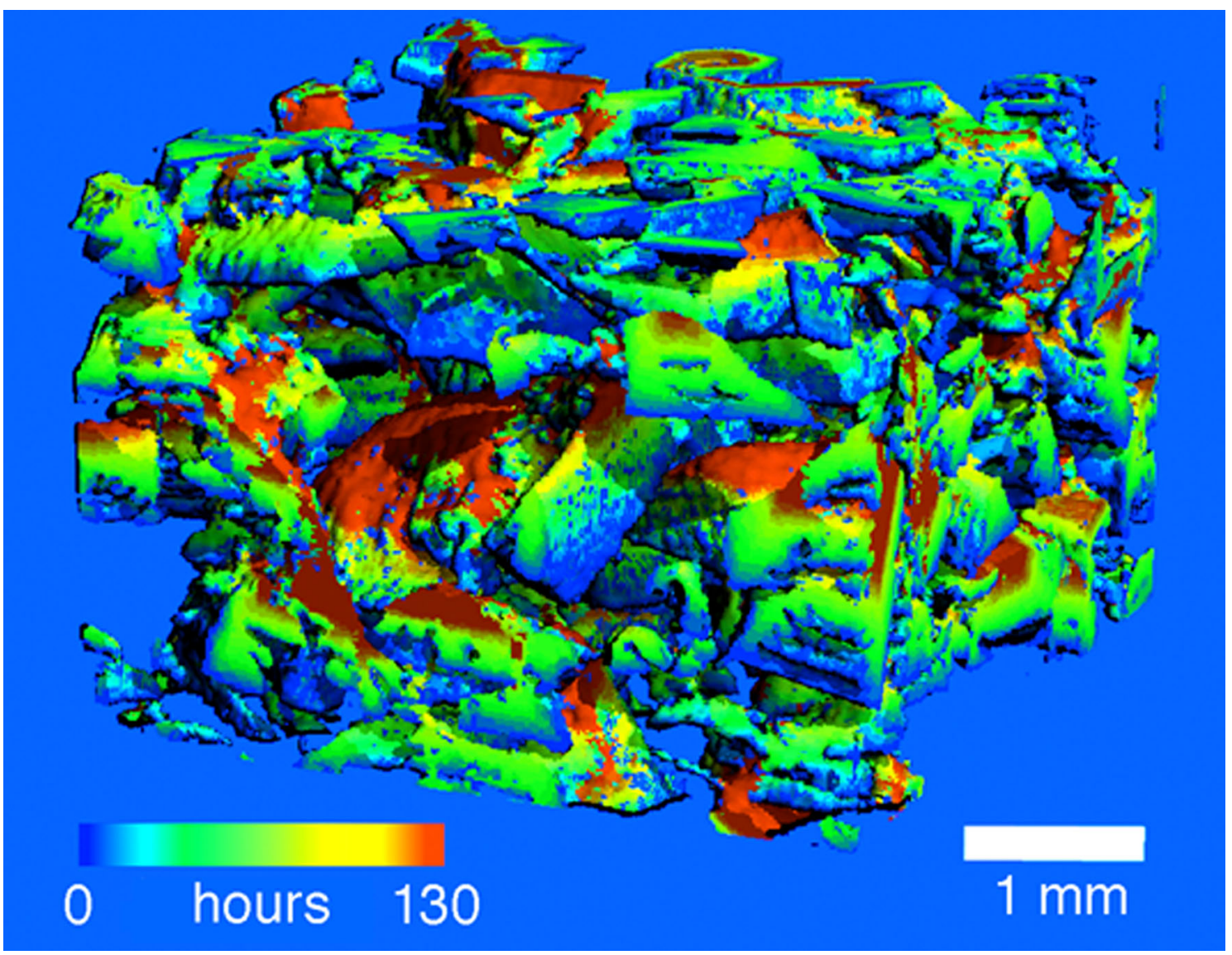

Fig. 3 Age distribution of ice in a depth hoar sample from a laboratory experiment. The depth hoar sample has been exposed to typical temperature gradients of an Arctic snowpack $\left(5^{\circ} \mathrm{K}\right.$ snow temperature increase per $10 \mathrm{~cm}$ depth). Depth hoar recrystallizes completely and the oldest parts of the sample are just 5-days old ice (dark red), although the snow was made 28 days before (M. Schneebeli, WSL-SLF, unpublished)

They have developed a holistic snow terminology integrating the effects on the ecology, grazing opportunities, and management of the herd (Fig. 4) which differs from scientific standard terms (Eira et al. 2013). However, the combination of traditional ecological knowledge (TEK) of reindeer herders with natural science measurements and snow classification may guide future strategies for a sustainable future of reindeer herding in a changing climate (Riseth et al. 2011; Eira et al. 2013). TEK in general has been formally recognized by the Arctic Council as important to understanding the Arctic (Arctic-Council 1996) and the Ottawa traditional knowledge principles can be found here: http://www.arcticpeoples.org/images/2015/ ottradknowlprinc.pdf.

\section{Extreme events}

Snow properties are increasingly impacted by extreme and anomalous events such as ROS (Rennert et al. 2009), icing (Bartsch et al. 2010; Hansen et al. 2013), and warming periods leading to unseasonal melt periods and isolated freeze-thaw cycles (Bokhorst et al. 2011; Semenchuk et al. 2013; Semmens et al. 2013; Wilson et al. 2013). These events are caused by different factors such as heavy rainfall (Rennert et al. 2009; Hansen et al. 2014) and movement of warm air masses through katabatic winds, e.g. Chinook (Fuller et al. 2009) and foehn winds (Pedersen et al. 2015). These extreme and anomalous events may be caused by different weather phenomena, but they all have the following in common: (1) they have an abrupt and sporadic nature, (2) they are unusual for the season in the geographical locations where they occur, (3) they cause changes in snowpack properties, and (4) they have immediate impacts on humans and ecosystems. Their temporal extent varies from a few hours to many days, and their spatial extent is controlled by the spatial scale of the driving weather phenomenon (e.g. synoptic).

The sparse distribution of meteorological stations and remoteness of areas across the Arctic region limit groundbased observation of extreme events, their effect on the 


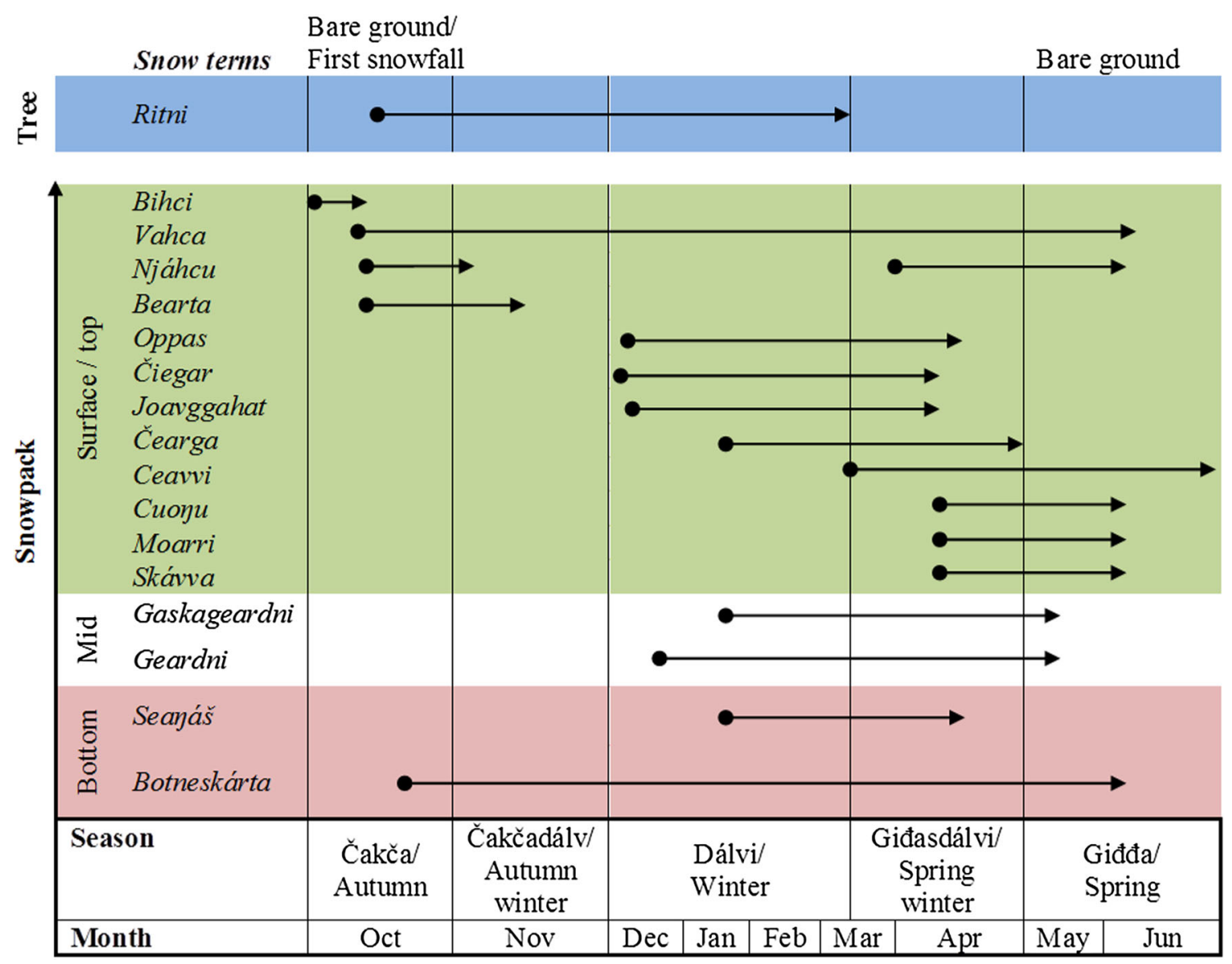

Fig. 4 Schematic overview of Sámi snow concepts used during the cold season in reindeer herding in Guovdageaidnu, sub-Arctic Norway. The concepts are shown as they occur in and above the snowpack (blue frost on trees, green snow formation related to the surface and snowpack top layer, white mid snowpack layer, pink illustrates bottom snow layer). The arrows illustrate the duration of different concepts used by reindeer herders. This figure is modified from Fig. 4 by Eira et al. (2013). Further descriptions of the snow characteristics, rather than position and timing, can be found in Riseth et al. (2011)

snowpack, and modelling efforts (e.g. Bulygina et al. 2010; Johansson et al. 2011; Hansen et al. 2014; Pedersen et al. 2015). However, Pedersen et al. (2015) quantified the spatially distributed snow property (SWE, snow depth, snow thermal resistance, and timing of snow-free date) changes associated with episodic snowmelt events through in situ snow observations, meteorological data, and snow modelling. Extreme events are also detectable through remote sensing using differencing 3-day averages of backscatter (Bartsch et al. 2010; Semmens et al. 2013; Wilson et al. 2013). Additionally, extreme events are detectable through modelling, e.g. by Liston and Hiemstra (2011) who showed an increased trend in ROS events over maritime regions of the Arctic since 1979. Observed (Hansen et al. 2014) and predicted (Bjerke et al. 2014) abrupt changes in snow properties and snow conditions associated with extreme events add complexity to the impacts of current warming in the Arctic (Walsh 2014).
Quantification and prediction of these extreme events requires increased research focus.

\section{MODELLING CHANGING SNOW CONDITIONS}

\section{Types and applications of snow models}

Terrestrial snow-cover models are used to simulate the snow temporal evolution in multiple hydrological, meteorological, climatological, glaciological, and ecological applications. Depending on the snow-model sophistication (i.e. the complexity of parameterisations used to describe snow properties and the processes taking place within the snow and at the interfaces with the atmosphere and the soil), some models can also simulate snow stratigraphy (i.e. the vertical evolution of snow properties in the various layers forming the snowpack). 
Simple (empirical) snow models have been widely used in impacts studies (e.g. Van Den Broeke et al. 2010; Saloranta 2012). These models have fewer data requirements (e.g. just temperature and precipitation) than physically based models, but require calibration. For example, Kumar et al. (2013) compared the impact of using a temperature index and a physically based snow model on streamflow simulations. They found that un-calibrated temperature-index models predict streamflow poorly. Therefore, simple empirical models need to be carefully calibrated in both time and space, whereas physically based snow and hydrological models provide better accuracy. In fact, even calibrated models may be unreliable outside their regions and periods of calibration (Bougamont et al. 2007). Moreover, models based on energy balance principles are essential when snow models are required to provide boundary conditions for atmospheric models in weather and climate prediction applications and physically based snow models therefore remain essential.

Three main categories of physically based snow models exist:

- Zero-layer (combined with soil) or single-layer snow models

- Intermediate complexity snow models accounting for some physical processes within the snowpack, typically with 2-5 model layers

- Detailed snowpack models

Snow models can be driven with measured or simulated meteorological data. Usually, the higher the snow model sophistication, the simpler the framework within which they are used. There are three main configurations in which snow models are run:

- Stand-alone models

- Coupled models with atmosphere, soil, and vegetation components

- Modules within Earth System Models (ESMs)

ESMs typically use zero- and single-layer snow models because they have few parameterisations leading to fast computations, but they have limitations. Successful attempts to couple intermediate complex snow models with atmospheric and soil models have been made (e.g. within numerical weather prediction (NWP) systems and ESMs such as HTESSEL (Dutra et al. 2010), RACMO (Kuipers Munneke et al. 2011), and CLM4 (Oleson et al. 2010). Detailed snowpack models are typically used in simple stand-alone configurations. Simulation results from these models provide the temporal evolution of snow properties with depth (Vionnet et al. 2012). It is possible to drive these sophisticated models either with weather station measurements or with atmospheric reanalyses (e.g. Brun et al. 2013). A similar approach is to use coarse-grid reanalyses or climate model fields downscaled to a fine scale grid in order to account for the strong horizontal variability caused, for example, by complex orography (Fiddes and Gruber 2014). The choice of input data depends on the application, and NWP data are used for snow prediction on large scales.

Recent developments within the NWP community have resulted in increased cooperation and interests among various disciplines (e.g. hydrology and ecology). The increased spatial resolution of NWP models increases their potential utility for user groups who depend on modelling regional- and local-scale processes. This is also supported by the development of off-line land-surface models which can be run stand-alone (e.g. Crocus snow physics model).

\section{Progress and key achievements in Arctic snow modelling}

Modelling snow cover accurately is important, particularly because of the crucial role it plays in energy transfer between the land and the atmosphere. Recent model intercomparison projects have improved our understanding of how snow models perform and have prompted developments in individual models and parameterisations of snow processes. In this section, we highlight some achievements in snow modelling and look forward to upcoming intercomparison experiments.

\section{Snow simulation achievements and limitations}

Phase 5 of the Coupled Model Inter-comparison Project (CMIP5; http://cmip-pcmdi.llnl.gov/cmip5/) provided an opportunity for assessing the simulation of snow in the current generation of climate models. Progress and limitations of CMIP5 models representing SWE, snow cover, and snowfall compared to observations and reanalyses have been identified (Brutel-Vuilmet et al. 2013; Kapnick and Delworth 2013; Terzago et al. 2014). A key result was that the decreasing trend in Northern Hemisphere spring snowcover extent over the 1979-2005 period (Derksen et al. 2015) was underestimated by CMIP5 models (BrutelVuilmet et al. 2013). Snow-albedo feedbacks were modelled well but the spread in modelled snow-albedo feedback has not narrowed since CMIP3, probably due to the widely varying treatment of the masking of snow-covered surfaces by vegetation in the models (Qu and Hall 2014). Most CMIP5 models overestimate the contrast in albedo between snow-covered and snow-free land, but fewer models had large cold temperature or high snow-cover biases in CMIP5 than in CMIP3 (Fletcher et al. 2015). Because snow cover forms an interface between the atmosphere and the land surface, differences in simulations of the insulating effect of snow leads to disagreements in 
modelled soil temperatures (Koven et al. 2013). Representation of snow properties may also affect the accuracy of air temperature calculated by climate models. Analysis of data from 48 CMIP5 models indicates that the calculated monthly-mean surface temperature for Northern Eurasia has the largest inter-model spread during the snowmelt period indicating that accurate representation of the snowmelt is needed to improve the overall performance of models and narrow the range of associated uncertainties in climate projections.

Large sets of simulations will soon be available from climate models and ESMs in CMIP6 (http://www.wcrpclimate.org/wgcm-cmip/wgcm-cmip6) and from standalone land-surface models in GSWP3 (http://hydro.iis.utokyo.ac.jp/GSWP3/intro.html). The CliC ESM-SnowMIP project (http://www.climate-cryosphere.org/activities/ targeted/esm-snowmip) has been initiated to assess the strengths and weaknesses of snow simulations in these experiments and to provide guidelines for the improvement of models.

\section{Snow model forcing data}

Improved simulations can result from improvements in the forcing data used to run snow models as well as from improvements in snow parameterizations. Snow-cover builds up due to solid precipitation and its properties are dramatically sensitive to liquid and mixed-phase precipitation. Though recent progress has been made (Marks et al. 2013; Mizukami et al. 2013), accurately partitioning precipitation into rain and snow remains a challenge. Multiple-year snow model forcing datasets with multiple evaluation data have recently been collated for several well-instrumented research sites in mid-latitude alpine locations (Brun et al. 2013), but there is a comparative lack of suitable data for the Arctic. For large-scale studies, global gridded forcing datasets available from reanalyses have been used successfully (e.g. Brun et al. 2013). ESMSnowMIP includes comparisons between snow simulations at reference sites with in situ forcing data and large-scale simulations using reanalyses or coupled atmospheric models.

\section{Snow parameterizations}

Physical parameterizations of snow metamorphism are important because snow microstructure determines snow properties, including those controlling energy exchanges at the snow/soil and snow/air interfaces. Specific surface area (SSA) has attracted attention as a microstructural property that determines the physical, optical, and chemical properties of snow (Domine et al. 2008). It affects microwave remote sensing (e.g. Brucker et al. 2011; Roy et al. 2013;
Picard et al. 2014) and it is now parameterized in some models (Carmagnola et al. 2014). SSA can now be measured in the field using observer-independent near-infrared sensors (Gallet et al. 2009; Arnaud et al. 2011; Montpetit et al. 2012). Process studies have identified weaknesses of snow models in simulating water percolation and ice-layer formation (e.g. Brucker et al. 2011; Wever et al. 2014). However, physically based snow models may help in identifying ice layers in the snow (Vikhamar-Schuler et al. 2013; Bjerke et al. 2014). Snow water mass still varies widely $(50 \%)$ among models and datasets relying solely on satellite-derived information show approximately $40 \%$ less total snow for the peak accumulation seasons, compared with retrievals combining satellite- and ground-based data (Mudryk et al. 2015).

\section{Modelling soil-snow-vegetation interactions}

Forests affect snow dynamics, and models have been developed to incorporate this (Essery 2013). However, there are still issues with simulated snow-albedo feedbacks and the transition from snow-covered to snow-free canopies when temperatures rise above freezing (Thackeray et al. 2014). Shrubs trap windblown snow thereby affecting snow distribution (Myers-Smith et al. 2011) and this effect may be accentuated by the expansion of shrubs in some Arctic regions (e.g. Pearson et al. 2013; Urban et al. 2014). The impact of snow-trapping by shrubs on soil temperatures and gas fluxes have been modelled (e.g. Lawrence and Swenson 2011; Menard et al. 2014), but these processes have not yet been included in dynamic vegetation models. Progress on modelling freeze-thaw processes has been made by increasing the numbers of layers and depth of soil models, but modelling of permafrost conditions is degraded by biases in snow-depth simulations (Slater and Lawrence 2013).

\section{Modelling contaminants in snow}

Models now parameterize the impacts of contaminants with different spectral properties on the snow-surface albedo (Qian et al. 2015), but it remains challenging to couple these parameterisations with the atmospheric transport and deposition of contaminants such as BC. Current aerosol models can simulate mean BC concentrations in snow reasonably well, but modelled distributions are poorly correlated with measurements; models generally underestimate $\mathrm{BC}$ concentrations in snow in northern Russia and Norway but overestimate BC elsewhere in the Arctic (Jiao et al. 2014). Algae and bacteria living in snow and ice are also considered contaminants, and the spectral properties of snow are affected by the species composition (Lutz et al. 2014). 
Table 3 Identification of knowledge gaps related to changing Arctic snow cover and its consequences: gaps, recommendations, and implementation strategy

\begin{tabular}{lll}
\hline Gaps & Recommendations & Implementation strategy \\
\hline
\end{tabular}

A. Observations

There are large spatial scaling issues that need to be resolved, from snow grain characteristics to the circumpolar Arctic region to the full Earth system.

The temporal evolution of the Arctic snowpack throughout an entire cold season is poorly investigated, specifically, the evolution of ice crusts and soil properties (temperature and soil frost depth) (a) Increase the number of stations for manual and automatic recording

(b) Develop remote sensing tools that can detect snow-depth differences across small scale landscape topography

(a) Initiate year-round ground observations are needed at intervals of hours or day

(b) Improve methods to derive reliable information at a proper spatial and temporal resolution from remote sensing techniques from both optical and active (SAR) and passive (radiometer) microwave spaceborne sensors

(c) Resolve technological difficulties in microwave and SAR (Synthetic Aperture Radar) remote sensing techniques

The Arctic is vast but is sparsely populated and observing power is limited

Ground-based observations of impacts of extreme events on the snowpack are limited

The effects of physical properties of the snowpack on sea ice have been measured but by out-dated methods and understanding of the snow-on-sea ice feedback is poor

The accuracy of remote sensing of SWE is limited by topography and forest cover (a) Extend the number of human-based snow measurements to obtain a more detailed grid of snow parameters across the Arctic Region

(b) Include citizen observations to extend the distribution of observations

Develop detection methods (manual and remote) to quantify and record impacts on the snowpack by extreme events

(a) Improvement in the application and development of new and coordinated methodologies are required

(b) Develop remote sensing techniques to quantify snowpack on sea ice

Develop and improve remote sensing techniques for quantification of SWE
For modelling of snow precipitation, reliable measurements of total precipitation and solid precipitation fractions are crucial for properly driving snow models

There is great variety in methods used between different long-term measuring stations (a) Increase the number of precipitation measuring stations to meet the needs of the modelling community

(b) Equip automated weather stations with instrumentation to estimate precipitation phase-such as optical disdrometers (SPICE)

Share and compare techniques between monitoring teams to increase the support for long-term complete validation sites with sensors probing the atmosphere, snow, and soil
INTERACT can provide Arctic-wide groundvalidation of RS techniques over multiple topographies

GEO Cold Regions Initiative can facilitate availability of remote sensing data through its Participant Organizations for intercomparison and validation efforts

INTERACT can provide additional measuring stations but needs information on methods and on making the data accessible

SPICE is evaluating current instrumentation (http://www.wmo.int/pages/prog/www/ IMOP/intercomparisons/SPICE/SPICE.html)

INTERACT is already compiling a list of methods used at research stations and will help implement new observations and methods 
Table 3 continued

\begin{tabular}{|c|c|c|}
\hline Gaps & Recommendations & Implementation strategy \\
\hline \multicolumn{3}{|l|}{ B. Modelling } \\
\hline $\begin{array}{l}\text { The spread of model output needs to be } \\
\text { reduced in relation to snow-albedo feedback, } \\
\text { most models overestimate the contrast in } \\
\text { albedo between snow-covered and snow- }\end{array}$ & $\begin{array}{l}\text { More accurate representation of the snowmelt } \\
\text { is needed to improve the overall } \\
\text { performance of the models and narrow the } \\
\text { range of associated uncertainties in climate }\end{array}$ & $\begin{array}{l}\text { WCRP CliC ESM-SnowMIP experiments } \\
\text { under CMIP6 will be investigating sources } \\
\text { of model spread in snow simulations and } \\
\text { their influence on climate }\end{array}$ \\
\hline
\end{tabular}
free land. Differences in simulations of the insulating effect of snow leads to disagreements in modelled soil temperatures

Aerosol models can simulate mean Black Carbon $(B C)$ concentrations in snow reasonably well, but modelled distributions are poorly correlated with measurements

Inclusion of particle transport from snow-free areas in GCM/regional snow models are needed and the simulation of surface albedo change due to dust deposition and microorganism growth

Potential feedbacks between snow and sea ice are of critical importance, but not experimentally investigated

Potential feedbacks between snow and freshwater ice are likely to be important because of the spatial coverage of tundra lakes and ponds. However, this has not been investigated in the field or in the laboratory while snow manipulation experiments on lake ice are absent

Progress on modelling soil freeze and thaw processes has been made by increasing the numbers of layers and depth of soil models, but modelling of permafrost conditions is degraded by biases in snow-depth simulations

Process studies have identified weaknesses of snow models in simulating water percolation and ice-layer formation

Impacts of changing snow conditions on teleconnections within the Arctic and with attention

C. Impacts studies

Effects of earlier or late snowmelt impacts on human well-being, such as physical injuries and degree of exposure of people to pathogens from various sources transported in snow and melt water

The snow science community urgently needs to quantify these feedbacks and include them in models if relevant

The snow science community needs to quantify these feedbacks and include them in models if relevant. Also, processes should be identified and quantified using experimental manipulations of snow analogues to those deployed on land

Snow-depth simulations need to be improved and coupling of snow and soil models is needed

Physically based snow models may help in identifying ice layers in the snow

Increase the modelling effort on how changing snow conditions impact on Arctic teleconnections

(a) Initiate base-line studies to assess the region large changes may be expected

(b) Promote research and monitoring other regions of Earth require more research current threats and where in the Arctic coordination across the Arctic for intercomparability of methodologies

Risk assessments need to be re-considered in light of changing snow conditions

indicate that these may be inaccurate

Ini

The direct impact of the temporal and
variability of snow on the economic

development of the Arctic, especially expressed in monetary value, is hard to evaluate. Determining these impacts is difficult as snow conditions are changing at the same time as economic growth management and the costs associated with lack of appropriate management
INTERACT can provide facilities around the Arctic for observations and experiments on feedbacks and for validation of models

WCRP CliC ESM-SnowMIP experiments under CMIP6 will be investigating sources of model spread in snow simulations and their influence on climate
INTERACT can help monitor spread of pathogens and vectors throughout the Arctic and is developing a coordinated system to do this

GEO Cold Regions Initiative can provide the societal benefits assessment and awareness crossing the GEO societal benefits areas via the GEO new work programme for 2016-2025 
Table 3 continued

\begin{tabular}{|c|c|c|}
\hline Gaps & Recommendations & Implementation strategy \\
\hline $\begin{array}{l}\text { The detailed timing of changes in snow cover } \\
\text { during the cold season is uncertain. These } \\
\text { include periods of snowpack build-up, mid- } \\
\text { winter rain events, spring snowmelt, and } \\
\text { timing as well as increased soil moisture } \\
\text { deficits later in the growing season }\end{array}$ & $\begin{array}{l}\text { From an ecosystem perspective there is a } \\
\text { pressing need to identify when the largest } \\
\text { changes in snow conditions will occur, e.g., } \\
\text { start, middle, or late winter }\end{array}$ & $\begin{array}{l}\text { INTERACT can facilitate to increase the } \\
\text { number of appropriate observations } \\
\text { National funding agencies need to be made } \\
\text { aware of the requirement of seasonal } \\
\text { monitoring and experiments }\end{array}$ \\
\hline $\begin{array}{l}\text { Impacts of changing snow conditions are } \\
\text { species-specific both for plants and animals. } \\
\text { However, species vary in the magnitude of } \\
\text { their contribution to key ecosystem } \\
\text { processes }\end{array}$ & $\begin{array}{l}\text { We need to identify which species are most } \\
\text { responsive to snow changes and why, and } \\
\text { how they will impact ecosystem processes } \\
\text { and surface feedback to climate }\end{array}$ & $\begin{array}{l}\text { INTERACT can facilitate to start appropriate } \\
\text { observations and host relevant experiments } \\
\text { Protocols for monitoring snow conditions and } \\
\text { impacts in the same places and at the same } \\
\text { scales need to be further developed in the } \\
\text { frame of CPMP }\end{array}$ \\
\hline $\begin{array}{l}\text { The influences of snow and ground ice on } \\
\text { vegetation have been investigated in some } \\
\text { models but these processes have not yet } \\
\text { been included in large scale dynamic } \\
\text { vegetation models }\end{array}$ & $\begin{array}{l}\text { Facilitate greater representation of snow-cover } \\
\text { in all its complexity including ice layers } \\
\text { needs to be developed in vegetation/ } \\
\text { ecosystem models }\end{array}$ & $\begin{array}{l}\text { GEO Cold Regions Initiative can initiate a } \\
\text { dedicated aim that may bridge the ecosystem } \\
\text { mapping and snow-cover interaction }\end{array}$ \\
\hline \multicolumn{3}{|l|}{ D. Linking and communicating } \\
\hline $\begin{array}{l}\text { Information exchange between science and } \\
\text { society is generally poor with inadequate } \\
\text { communication. Sometimes there is low } \\
\text { relevance of the science for community } \\
\text { needs. On the other hand, there are } \\
\text { sometimes excessive expectations of } \\
\text { governments on researchers and lack of } \\
\text { understanding of science by policy makers }\end{array}$ & $\begin{array}{l}\text { (a) Facilitate information exchange between } \\
\text { society and the science community } \\
\text { (b) Inform communities of ongoing and } \\
\text { projected changes relevant at the local scale } \\
\text { (c) Design observation strategies for traditional } \\
\text { science to work together with citizens }\end{array}$ & $\begin{array}{l}\text { INTERACT offers a system for } \\
\text { communication between field researchers } \\
\text { and local communities and has outreach } \\
\text { activities } \\
\text { GEO Cold regions aims to establish a proactive } \\
\text { framework for the development of } \\
\text { information and related services over Cold } \\
\text { Region: the Global Cold Regions } \\
\text { Community Portal }\end{array}$ \\
\hline $\begin{array}{l}\text { The Arctic science community is well } \\
\text { integrated and coordinated by various } \\
\text { organizations but their agendas for research } \\
\text { and monitoring, for example of snow cover, } \\
\text { are often implemented independently, even } \\
\text { though there are numerous interactions } \\
\text { within the Arctic and Earth systems }\end{array}$ & $\begin{array}{l}\text { (a) Improve the integration between } \\
\text { activities-monitoring, modelling, and } \\
\text { evaluating impacts-and between Earth } \\
\text { system domains--terrestrial, marine, } \\
\text { atmospheric, and freshwater. } \\
\text { (b) We need to establish archives (metadata } \\
\text { portals) and/or a hub of in situ snow products } \\
\text { that are relevant for the snow science } \\
\text { disciplines and communicate awareness of } \\
\text { the existence of these archives to other end- } \\
\text { users (Policy makers and society) }\end{array}$ & $\begin{array}{l}\text { GEO Cold Regions can help by bridging the } \\
\text { different activities, domains, and } \\
\text { communities (remote sensing and in situ) in } \\
\text { the field of cold regions' earth observations } \\
\text { GEO Cold Regions is promoting free access to } \\
\text { the earth observations data over the Cold } \\
\text { Regions, including the Global Observation } \\
\text { System of Systems (GEOSS) products and } \\
\text { GEOSS-DataCORE }\end{array}$ \\
\hline
\end{tabular}

\section{CURRENT GAPS AND RECOMMENDATIONS FOR FUTURE RESEARCH AND IMPLEMENTATION PLANS}

Without duplicating recommendations suggested by other programmes (AMAP 2011), our intention was to review and up-date the perceived gaps in current research activities on Arctic snow changes as a contribution to the ICARP III process towards a roadmap for future research. To focus these developments, we identified key gaps, formulate recommendations, and seek commitments by stakeholders and major Arctic and Global organisations to implement these recommendations (Table 3 ). In addition, many detailed requirements exist which are listed in Supplementary material S1. A key limitation to progress on determining changes in Arctic snow cover and their consequences is a lack of integration among domains (land, sea, lakes, and atmosphere) and between approaches. Monitoring of snow identifies change but needs to be linked to manipulations of climate, environment, and ecosystems to understand the impacts. This understanding needs to be linked to modelling at relevant scales that project into the future (or past). With this predictive capability, knowledge-based management may be developed and implemented (Johansson et al. 2012). One possibility to improve integration of activities across domains and approaches is to develop coordinated activities, hosted by a regional or global organization.

Therefore, in order to develop ESM that can be used in the documentation and/or prediction of snow-cover 


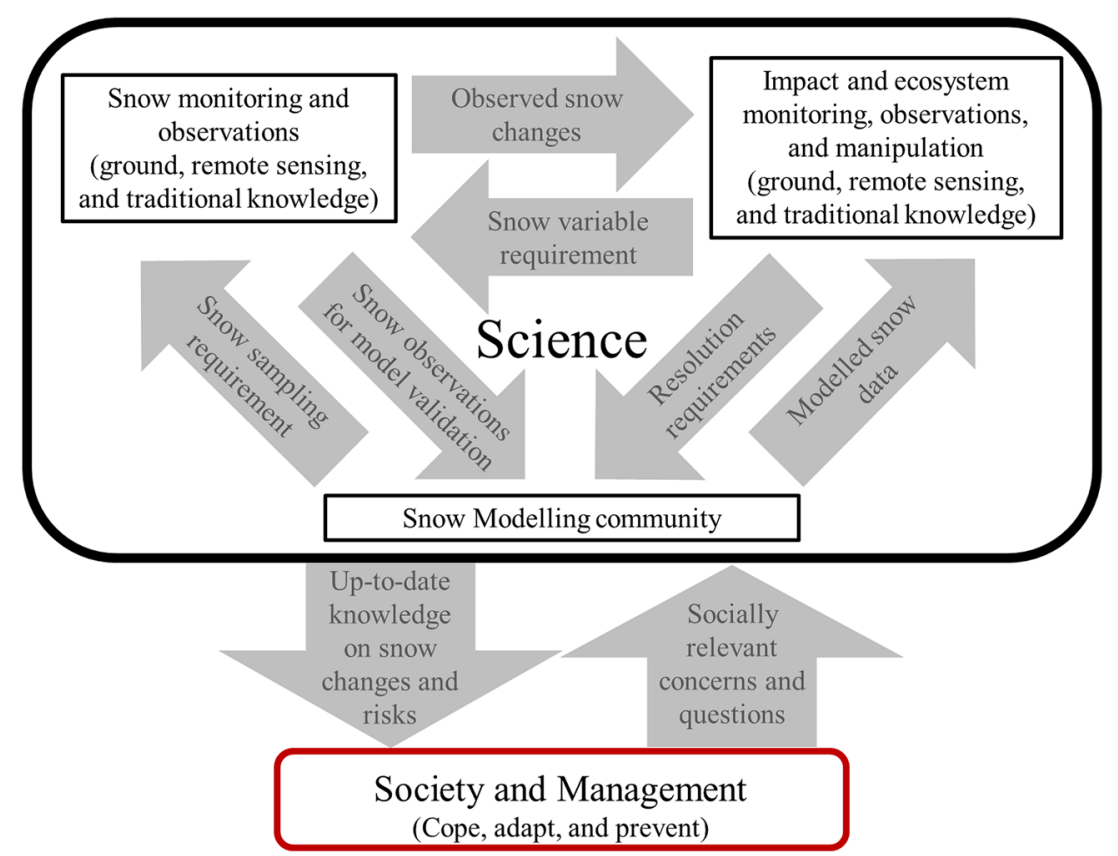

Fig. 5 Conceptual model of required interactions between society and management and science including the snow monitoring, snow modelling, and snow-impact communities

changes and their impacts, there is a need for improved communication and cooperation between discipline-specific communities (ecologist/biologist, social scientists, and snow scientist) and between the approaches (monitoring/ observers in the field/remote sensing and modellers) (Fig. 5). For instance, ecologists need to identify at which spatial and temporal resolutions snow-cover changes are relevant and make this known to the modelling community. This will assure that the outputs of modelled snow variables match the given resolution of ecosystem processes and dynamics. Conversely, modellers require validation data of snow variables on relevant scales (Table 1). Therefore, the timing, frequency, and spatial resolution of snow surveys and snow monitoring should match the snowmodel resolution in order to generate useful snow outputs for the ecosystem scientists/snow-impact community (Fig. 5). For this interaction to be successful, detailed cross-disciplinary coordination of field campaigns, monitoring, research projects, and model development is required.

Since society and its infrastructure have to cope with the challenges of changing snow conditions (Fig. 1), it requires easy access to snow predictions. Therefore, an open dialogue needs to be established or expanded to facilitate information exchange between society and the science community. Implementation of these recommendations should ideally be considered by organizations, such as the Arctic Council, that span science and human dimensions. Integration between the different snow disciplines and communication to end-users could be achieved through the ICARP process and associated organizations IASC, INTERACT, CliC, GEO (GEOSS), and WMO (GCW). With this paper, we have attempted to provide a basis, and stimulus, for the implementation of key priorities (Table 3 ) to address the limitations in our understanding of Arctic snow conditions and how they may change in the near future.

Acknowledgments The writing of this paper was initiated by an IASC ICARP III Activity grant to TVC enabling a workshop hosted by the European Environment Agency. The authors acknowledge funding from their respective national and international funding bodies, which has enabled the contribution of all authors to this work.

Open Access This article is distributed under the terms of the Creative Commons Attribution 4.0 International License (http:// creativecommons.org/licenses/by/4.0/), which permits unrestricted use, distribution, and reproduction in any medium, provided you give appropriate credit to the original author(s) and the source, provide a link to the Creative Commons license, and indicate if changes were made.

\section{REFERENCES}

Alou-Font, E., C.J. Mundy, S. Roy, M. Gosselin, and S. Agusti. 2013. Snow cover affects ice algal pigment composition in the coastal Arctic Ocean during spring. Marine Ecology Progress Series 474: 89-104.

AMAP. 2011. Snow, water, Ice and Permafrost in the Arctic (SWIPA): Climate change and the cryosphere, xii-538. Oslo: Arctic Monitoring and Assessment Programme (AMAP). 
Aoki, T., S. Matoba, S. Yamaguchi, et al. 2014. Light-absorbing snow impurity concentrations measured on Northwest Greenland ice sheet in 2011 and 2012. Bulletin of Glaciological Research 32: 21-31.

Arctic-Council. 1996. Declaration on the establishment of the Arctic Council, 1-5. Ottawa: Arctic-Council.

Arnaud, L., G. Picard, N. Champollion, et al. 2011. Measurement of vertical profiles of snow specific surface area with a $1 \mathrm{~cm}$ resolution using infrared reflectance: Instrument description and validation. Journal of Glaciology 57: 17-29.

Ask, J., J. Karlsson, L. Persson, P. Ask, P. Byström, and M. Jansson. 2009. Terrestrial organic matter and light penetration: Effects on bacterial and primary production in lakes. Limnology and Oceanography 54: 2034-2040.

Avanzi, F., M. Caruso, C. Jommi, C. De Michele, and A. Ghezzi. 2014. Continuous-time monitoring of liquid water content in snowpacks using capacitance probes: A preliminary feasibility study. Advances in Water Resources 68: 32-41.

Barichivich, J., K.R. Briffa, R.B. Myneni, et al. 2013. Large-scale variations in the vegetation growing season and annual cycle of atmospheric CO2 at high northern latitudes from 1950 to 2011. Global Change Biology 19: 3167-3183.

Bartsch, A., T. Kumpula, B.C. Forbes, and F. Stammler. 2010. Detection of snow surface thawing and refreezing in the Eurasian Arctic with QuikSCAT: Implications for reindeer herding. Ecological Applications 20: 2346-2358.

Bernard, E., J.M. Friedt, F. Tolle, M. Griselin, G. Martin, D. Laffly, and C. Marlin. 2013. Monitoring seasonal snow dynamics using ground based high resolution photography (Austre Lovenbreen, Svalbard, $79^{\circ} \mathrm{N}$ ). ISPRS Journal of Photogrammetry and Remote Sensing 75: 92-100.

Biedunkiewicz, A., and E. Ejdys. 2011. Icicles as carriers of yeastlike fungi potentially pathogenic to human. Aerobiologia 27: 333-337.

Bilodeau, F., G. Gauthier, and D. Berteaux. 2013. Effect of snow cover on the vulnerability of lemmings to mammalian predators in the Canadian Arctic. Journal of Mammalogy 94: 813-819.

Bjerke, J.W., S.R. Karlsen, K.A. Høgda, et al. 2014. Record-low primary productivity and high plant damage in the Nordic Arctic Region in 2012 caused by multiple weather events and pest outbreaks. Environmental Research Letters 9: 084006.

Bjerke, J.W., H. Tømmervik, M. Zielke, and M. Jørgensen. 2015. Impacts of snow season on ground-ice accumulation, soil frost and primary productivity in a grassland of sub-Arctic Norway. Environmental Research Letters 10: 095007.

Bokhorst, S., J.W. Bjerke, M. Davey, et al. 2010. Impacts of extreme winter warming events on plant physiology in a sub-Arctic heath community. Physiologia Plantarum 140: 128-140.

Bokhorst, S., J.W. Bjerke, L. Street, T.V. Callaghan, and G.K. Phoenix. 2011. Impacts of multiple extreme winter warming events on sub-Arctic heathland: phenology, reproduction, growth, and $\mathrm{CO}_{2}$ flux responses. Global Change Biology 17: 2817-2830.

Bokhorst, S., G.K. Phoenix, J.W. Bjerke, T.V. Callaghan, F. HuyerBrugman, and M.P. Berg. 2012. Extreme winter warming events more negatively impact small rather than large soil fauna: Shift in community composition explained by traits not taxa. Global Change Biology 18: 1152-1162.

Bokhorst, S., D.B. Metcalfe, and D.A. Wardle. 2013. Reduction in snow depth negatively affects decomposers but impact on decomposition rates is substrate dependent. Soil Biology \& Biochemistry 62: 157-164.

Borzenkova, A.B., and A.B. Shmakin. 2012. Changes in the snow cover thickness and of daily snowfall intensity affecting the highways cleaning expenses in Russian cities. Ice and Snow 2: 59-70.
Bougamont, M., J.L. Bamber, J.K. Ridley, et al. 2007. Impact of model physics on estimating the surface mass balance of the Greenland ice sheet. Geophysical Research Letters. doi:10.1029/ 2007GL030700.

Bowden, J.J., A. Eskildsen, R.R. Hansen, K. Olsen, C.M. Kurle, and T.T. Høye. 2015. High-Arctic butterflies become smaller with rising temperatures. Biology Letters 11: 20150574.

Brown, L.C., and C.R. Duguay. 2010. The response and role of ice cover in lake-climate interactions. Progress in Physical Geography 34: 671-704.

Brucker, L., and T. Markus. 2013. Arctic-scale assessment of satellite passive microwave-derived snow depth on sea ice using Operation IceBridge airborne data. Journal of Geophysical Research-Oceans 118: 2892-2905.

Brucker, L., A. Royer, G. Picard, A. Langlois, and M. Fily. 2011. Hourly simulations of the microwave brightness temperature of seasonal snow in Quebec, Canada, using a coupled snow evolution-emission model. Remote Sensing of Environment 115: 1966-1977.

Brun, E., V. Vionnet, A. Boone, et al. 2013. Simulation of northern Eurasian local snow depth, mass, and density using a detailed snowpack model and meteorological reanalyses. Journal of Hydrometeorology 14: 203-219.

Brutel-Vuilmet, C., M. Ménégoz, and G. Krinner. 2013. An analysis of present and future seasonal Northern Hemisphere land snow cover simulated by CMIP5 coupled climate models. The Cryosphere 7: 67-80.

Bulygina, O.N., P.Y. Groisman, V.N. Razuvaev, and V.F. Radionov. 2010. Snow cover basal ice layer changes over Northern Eurasia since 1966. Environmental Research Letters 5: 015004.

Caduff, R., A. Wiesmann, Y. Bühler, and C. Pielmeier. 2015. Continuous monitoring of snowpack displacement at high spatial and temporal resolution with terrestrial radar interferometry. Geophysical Research Letters 42: 813-820.

Callaghan, T., M. Johansson, R. Brown, et al. 2011. The changing face of Arctic snow cover: A synthesis of observed and projected changes. Ambio 40: 17-31.

Carmagnola, C.M., S. Morin, M. Lafaysse, et al. 2014. Implementation and evaluation of prognostic representations of the optical diameter of snow in the SURFEX/ISBA-Crocus detailed snowpack model. The Cryosphere 8: 417-437.

Cavalieri, D.J., T. Markus, A. Ivanoff, et al. 2012. A comparison of snow depth on sea ice retrievals using airborne altimeters and an AMSR-E simulator. IEEE Transactions on Geoscience and Remote Sensing 50: 3027-3040.

Cheng, B., T. Vihma, L. Rontu, A. Kontu, H.K. Pour, C. Duguay, and J. Pulliainen. 2014. Evolution of snow and ice temperature, thickness and energy balance in Lake Orajärvi, northern Finland. Tellus A. doi:10.3402/tellusa.v3466.21564.

Clarke, G.K.C., A.H. Jarosch, F.S. Anslow, V. Radic, and B. Menounos. 2015. Projected deglaciation of western Canada in the twenty-first century. Nature Geoscience 8: 372-377.

Cohen, J., J. Jones, J.C. Furtado, and E. Tziperman. 2013. Warm Arctic, cold continents a common pattern related to Arctic sea ice melt, snow advance, and extreme winter weather. Oceanography 26: $152-160$.

Cohen, J., J.C. Furtado, J. Jones, M. Barlow, D. Whittleston, and D. Entekhabi. 2014. Linking Siberian snow cover to precursors of stratospheric variability. Journal of Climate 27: 5422-5432.

Cooper, E.J. 2014. Warmer shorter winters disrupt Arctic terrestrial ecosystems. Annual Review of Ecology Evolution and Systematics 45: 271-295.

Crook, J.A., P.M. Forster, and N. Stuber. 2011. Spatial patterns of modeled climate feedback and contributions to temperature response and Polar amplification. Journal of Climate 24: $3575-3592$. 
Deems, J.S., T.H. Painter, and D.C. Finnegan. 2013. Lidar measurement of snow depth: A review. Journal of Glaciology 59: 467-479.

Denoth, A. 1994. An electronic devise for long-term snow wetness recording. Annals of Glaciology 19: 104-106.

Derksen, C., R. Brown, L. Mudryk, and K. Luojus. 2015. Arctic: Terrestrial Snow. State of the Climate in 2014. J. Blunden and D. S. Arndt. Bulletin of the American Meteorological Society 96: 133-135.

Dibike, Y., T. Prowse, B. Bonsal, L. de Rham, and T. Saloranta. 2012. Simulation of North American lake-ice cover characteristics under contemporary and future climate conditions. International Journal of Climatology 32: 695-709.

Doherty, S.J., T.C. Grenfell, S. Forsstrom, D.L. Hegg, R.E. Brandt, and S.G. Warren. 2013. Observed vertical redistribution of black carbon and other insoluble light-absorbing particles in melting snow. Journal of Geophysical Research-Atmospheres 118: 5553-5569.

Domine, F., M. Albert, T. Huthwelker, et al. 2008. Snow physics as relevant to snow photochemistry. Atmospheric Chemistry and Physics 8: 171-208.

Douglas, T.A., L.L. Loseto, R.W. Macdonald, et al. 2012. The fate of mercury in Arctic terrestrial and aquatic ecosystems: A review. Environmental Chemistry 9: 321-355.

Duguay, C.R., M. Bernier, Y. Gauthier, and A. Kouraev. 2015. Remote sensing of lake and river ice. In Remote sensing of the cryosphere, ed. M. Tedesco, 273-306. Oxford: Wiley-Blackwell.

Dumont, M., E. Brun, G. Picard, et al. 2014. Contribution of lightabsorbing impurities in snow to Greenland's darkening since 2009. Nature Geoscience 7: 509-512.

Dupuis, A.P., and B.J. Hann. 2009. Climate change, diapause termination and zooplankton population dynamics: An experimental and modelling approach. Freshwater Biology 54: 221-235.

Dutra, E., G. Balsamo, P. Viterbo, P.M.A. Miranda, A. Beljaars, C. Schär, and K. Elder. 2010. An improved snow scheme for the ECMWF land surface model: Description and offline validation. Journal of Hydrometeorology 11: 899-916.

Eckerstorfer, M., and H.H. Christiansen. 2012. Meteorology, topography and snowpack conditions causing two extreme mid-winter slush and wet slab avalanche periods in high Arctic maritime Svalbard. Permafrost and Periglacial Processes 23: 15-25.

Eira, I.M.G., C. Jaedicke, O.H. Magga, N.G. Maynard, D. VikhamarSchuler, and S.D. Mathiesen. 2013. Traditional Sami snow terminology and physical snow classification-Two ways of knowing. Cold Regions Science and Technology 85: 117-130.

Ejdys, E., A. Biedunkiewicz, M. Dynowska, and E. Sucharzewska. 2014. Snow in the city as a spore bank of potentially pathogenic fungi. Science of the Total Environment 470: 646-650.

Essery, R. 2013. Large-scale simulations of snow albedo masking by forests. Geophysical Research Letters 40: 5521-5525.

Essery, R., S. Morin, Y. Lejeune, and C.B. Ménard. 2013. A comparison of 1701 snow models using observations from an alpine site. Advances in Water Resources 55: 131-148.

Fiddes, J., and S. Gruber. 2014. TopoSCALE v. 1.0: Downscaling gridded climate data in complex terrain. Geoscientific Model Development 7: 387-405.

Fierz, C.R., R.L. Armstrong, Y. Durand, P. Etchevers, E. Greene, D.M. McClung, K. Nishimura, P.K. Satyawali, and S.A. Sokratov. 2009. The international classification for seasonal snow on the ground. Paper presented at the UNESCO-IHP, Paris, France.

Fletcher, C.G., C.W. Thackeray, and T.M. Burgers. 2015. Evaluating biases in simulated snow albedo feedback in two generations of climate models. Journal of Geophysical Research-Atmospheres 120: $12-26$.
Francis, J.A., and S.J. Vavrus. 2012. Evidence linking Arctic amplification to extreme weather in mid-latitudes. Geophysical Research Letters 39: L06801.

Fuller, M.C., T. Geldsetzer, and J.J. Yackel. 2009. Surface-based polarimetric C-band microwave scatterometer measurements of snow during a Chinook event. IEEE Transactions on Geoscience and Remote Sensing 47: 1766-1776.

Gallet, J.C., F. Domine, C.S. Zender, and G. Picard. 2009. Measurement of the specific surface area of snow using infrared reflectance in an integrating sphere at 1310 and $1550 \mathrm{~nm}$. Cryosphere 3: 167-182.

Hachikubo, A., S. Yamaguchi, H. Arakawa, et al. 2014. Effects of temperature and grain type on time variation of snow specific surface area. Bulletin of Glaciological Research 32(1): 33-45.

Hall, D.K., G.A. Riggs, and V.V. Salomonson. 2006. MODIS snow and sea ice products. In Earth science satellite remote sensing, vol. I: Science and Instruments, ed. J.J. Qu, W. Gao, M. Kafatos, R.E. Murphy, and V.V. Salomonson, 154-181. New York: Springer.

Hall, D.K., G.A. Riggs, V.V. Salomonson, N.E. DiGirolamo, and K.J. Bayr. 2002. MODIS snow-cover products. Remote Sensing of Environment 83: 181-194.

Hanbali, R.M. 1994. Economic impact of winter road maintenance on road users. Transportation Research Record 1442: 151-161.

Hanewinkel, M., S. Hummel, and A. Albrecht. 2011. Assessing natural hazards in forestry for risk management: A review. European Journal of Forest Research 130: 329-351.

Hansen, B.B., V. Grøtan, R. Aanes, et al. 2013. Climate events synchronize the dynamics of a resident vertebrate community in the high Arctic. Science 339: 313-315.

Hansen, B.B., K. Isaksen, R.E. Benestad, et al. 2014. Warmer and wetter winters: Characteristics and implications of an extreme weather event in the High Arctic. Environmental Research Letters 9: 114021.

Havens, S., H.-P. Marshall, J.B. Johnson, and B. Nicholson. 2014. Calculating the velocity of a fast-moving snow avalanche using an infrasound array. Geophysical Research Letters 41: 6191-6198.

Haynes, K.M., and C.P.J. Mitchell. 2012. Inter-annual and spatial variability in hillslope runoff and mercury flux during spring snowmelt. Journal of Environmental Monitoring 14: 2083-2091.

Heilig, A., M. Schneebeli, and O. Eisen. 2009. Upward-looking ground-penetrating radar for monitoring snowpack stratigraphy. Cold Regions Science and Technology 59: 152-162.

Heilig, A., C. Mitterer, L. Schmid, N. Wever, J. Schweizer, H.P. Marshall, and O. Eisen. 2015. Seasonal and diurnal cycles of liquid water in snow-Measurements and modeling. Journal of Geophysical Research: Earth Surface. doi:10.1002/2015JF003593.

Holemann, J.A., M. Schirmacher, and A. Prange. 2005. Seasonal variability of trace metals in the Lena River and the southeastern Laptev Sea: Impact of the spring freshet. Global and Planetary Change 48: 112-125.

Hori, M., T. Aoki, T. Tanikawa, K. Kuchiki, M. Niwano, S. Yamaguchi, and S. Matoba. 2014. Dependence of thermal infrared emissive behaviors of snow cover on the surface snow type. Bulletin of Glaciological Research 32: 33-45.

Ims, R.A., N.G. Yoccoz, and S.T. Killengreen. 2011. Determinants of lemming outbreaks. Proceedings of the National Academy of Sciences of the United States of America 108: 1970-1974.

Jeelani, G., J.J. Feddema, C.J. van der Veen, and L. Stearns. 2012. Role of snow and glacier melt in controlling river hydrology in Liddar watershed (western Himalaya) under current and future climate. Water Resources Research 48: W12508.

Jiao, C., M.G. Flanner, Y. Balkanski, et al. 2014. An AeroCom assessment of black carbon in Arctic snow and sea ice. Atmospheric Chemistry and Physics 14: 2399-2417. 
Johansson, C., V.A. Pohjola, C. Jonasson, and T.V. Callaghan. 2011. Multi-decadal changes in snow characteristics in sub-Arctic Sweden. Ambio 40: 566-574.

Johansson, M., C. Jonasson, M. Sonesson, and T.R. Christensen. 2012. The man, the myth, the legend: Professor Terry V. Callaghan and his 3M concept. Ambio 41: 175-177.

Kapnick, S.B., and T.L. Delworth. 2013. Controls of global snow under a changed climate. Journal of Climate 26: 5537-5562.

Kelly, R. 2009. The AMSR-E snow depth algorithm: Description and initial results. Journal of The Remote Sensing Society of Japan 29: 307-317.

Koch, F., M. Prasch, L. Schmid, J. Schweizer, and W. Mauser. 2014. Measuring snow liquid water content with low-cost GPS receivers. Sensors 14: 20975-20999.

Koven, C.D., W.J. Riley, and A. Stern. 2013. Analysis of permafrost thermal dynamics and response to climate change in the CMIP5 earth system models. Journal of Climate 26: 1877-1900.

Krenke, A.N., E.A. Cherenkova, and M.M. Chernavskaya. 2012. Stability of snow cover on the territory of Russia in relation to climate change. Ice and Snow 1: 29-37.

Kuipers Munneke, P., M.R. van den Broeke, J.T.M. Lenaerts, M.G. Flanner, A.S. Gardner, and W.J. van de Berg. 2011. A new albedo parameterization for use in climate models over the Antarctic ice sheet. Journal of Geophysical Research: Atmospheres. doi:10.1029/2010JD015113.

Kumar, M., D. Marks, J. Dozier, M. Reba, and A. Winstral. 2013. Evaluation of distributed hydrologic impacts of temperatureindex and energy-based snow models. Advances in Water Resources 56: 77-89.

Kurtz, N., J. Richter-Menge, S. Farrell, M. Studinger, J. Paden, J. Sonntag, and J. Yungel. 2013. IceBridge airborne survey data support Arctic sea ice predictions. Eos, Transactions American Geophysical Union 94: 41-41.

Langford, H., A. Hodson, S. Banwart, and C. Boggild. 2010. The microstructure and biogeochemistry of Arctic cryoconite granules. Annals of Glaciology 51: 87-94.

Lawrence, D.M., and S.C. Swenson. 2011. Permafrost response to increasing Arctic shrub abundance depends on the relative influence of shrubs on local soil cooling versus large-scale climate warming. Environmental Research Letters 6: 045504.

Leinss, S., G. Parrella, and I. Hajnsek. 2014. Snow height determination by polarimetric phase differences in X-Band SAR data. IEEE Journal of Selected Topics in Applied Earth Observations and Remote Sensing 7: 3794-3810.

Liston, G.E., and C.A. Hiemstra. 2011. The changing cryosphere: Pan-Arctic snow trends (1979-2009). Journal of Climate 24: 5691-5712.

Lund-Hansen, L., I. Hawes, B. Sorrell, and M. Nielsen. 2014. Removal of snow cover inhibits spring growth of Arctic ice algae through physiological and behavioral effects. Polar Biology 37: 471-481.

Lutz, S., A.M. Anesio, S.E.J. Villar, and L.G. Benning. 2014. Variations of algal communities cause darkening of a Greenland glacier. FEMS Microbiology Ecology 89: 402-414.

Marks, D., A. Winstral, M. Reba, J. Pomeroy, and M. Kumar. 2013. An evaluation of methods for determining during-storm precipitation phase and the rain/snow transition elevation at the surface in a mountain basin. Advances in Water Resources 55: 98-110.

Marshall, H-P., G. Koh, and R.R. Forster. 2005. Estimating alpine snowpack properties using FMCW radar. Annals of Glaciology 40: $157-162$

Matsumoto, N., and T. Hoshino. 2009. Fungi in snow environments: psychrophilic molds-A group of pathogens affecting plants under snow. Enfield: Science Publishers Inc.

Matsumura, S., X. Zhang, and K. Yamazaki. 2014. Summer Arctic atmospheric circulation response to spring Eurasian snow cover and its possible linkage to accelerated sea ice decrease. Journal of Climate 27: 6551-6558.

Matzl, M., and M. Schneebeli. 2006. Measuring specific surface area of snow by near-infrared photography. Journal of Glaciology 52: $558-564$.

McCreight, J.L., E.E. Small, and K.M. Larson. 2014. Snow depth, density, and SWE estimates derived from GPS reflection data: Validation in the western U.S. Water Resources Research 50: 6892-6909.

McKinnon, L., D. Berteaux, G. Gauthier, and J. Bêty. 2013. Predatormediated interactions between preferred, alternative and incidental prey in the arctic tundra. Oikos 122: 1042-1048.

Meltofte, H. 2013. Arctic biodiversity assessment. Status and trends in Arctic biodiversity. Akureyri: Conservation of Arctic Flora and Fauna.

Menard, C.B., R. Essery, and J. Pomeroy. 2014. Modelled sensitivity of the snow regime to topography, shrub fraction and shrub height. Hydrology and Earth System Sciences 18: 2375-2392.

Michel, D., R. Philipona, C. Ruckstuhl, R. Vogt, and L. Vuilleumier. 2008. Performance and uncertainty of CNR1 net radiometers during a one-year field comparison. Journal of Atmospheric and Oceanic Technology 25: 442-451.

Mitterer, C., A. Heilig, J. Schweizer, and O. Eisen. 2011. Upwardlooking ground-penetrating radar for measuring wet-snow properties. Cold Regions Science and Technology 69: 129-138.

Mizukami, N., V. Koren, M. Smith, D. Kingsmill, Z. Zhang, B. Cosgrove, and Z. Cui. 2013. The impact of precipitation type discrimination on hydrologic simulation: Rain-snow partitioning derived from HMT-West radar-detected brightband height versus surface temperature data. Journal of Hydrometeorology 14: 1139-1158.

Montpetit, B., A. Royer, A. Langlois, et al. 2012. New shortwave infrared albedo measurements for snow specific surface area retrieval. Journal of Glaciology 58: 941-952.

Mudryk, L.R., C. Derksen, P.J. Kushner, and R. Brown. 2015. Characterization of northern hemisphere snow water equivalent datasets, 1981-2010. Journal of Climate 28: 8037-8051.

Myers-Smith, I.H., and D.S. Hik. 2013. Shrub canopies influence soil temperatures but not nutrient dynamics: An experimental test of tundra snow-shrub interactions. Ecology and Evolution 3: 3683-3700.

Myers-Smith, I.H., B.C. Forbes, M. Wilmking, et al. 2011. Shrub expansion in tundra ecosystems: Dynamics, impacts and research priorities. Environmental Research Letters 6: 045509.

Niemi, J., and J. Ahlstedt. 2012. Finnish agriculture and rural industries, 112a. Helsinki: Agrifood Research.

Nolet, B.A., S. Bauer, N. Feige, Y.I. Kokorev, I.Y. Popov, and B.S. Ebbinge. 2013. Faltering lemming cycles reduce productivity and population size of a migratory Arctic goose species. Journal of Animal Ecology 82: 804-813.

Oleson, K.W., D.M. Lawrence, B. Gordon, et al. 2010. Technical description of version 4.0 of the community land model (CLM). NCAR Technical Notes.

Panzer, B., D. Gomez-Garcia, C. Leuschen, et al. 2013. An ultrawideband, microwave radar for measuring snow thickness on sea ice and mapping near-surface internal layers in polar firn. Journal of Glaciology 59: 244-254.

Parham, P.E., J. Waldock, G.K. Christophides, et al. 2015. Climate, environmental and socio-economic change: weighing up the balance in vector-borne disease transmission. Philosophical Transactions of the Royal Society of London B: Biological Sciences 370: 20130557.

Pearson, R.G., S.J. Phillips, M.M. Loranty, P.S.A. Beck, T. Damoulas, S.J. Knight, and S.J. Goetz. 2013. Shifts in Arctic vegetation and associated feedbacks under climate change. Nature Climate Change 3: 673-677. 
Pedersen, S.H., G.E. Liston, M.P. Tamstorf, A. Westergaard-Nielsen, and N.M. Schmidt. 2015. Quantifying episodic snowmelt events in Arctic ecosystems. Ecosystems 18: 839-856.

Picard, G., A. Royer, L. Arnaud, and M. Fily. 2014. Influence of meter-scale wind-formed features on the variability of the microwave brightness temperature around Dome C in Antarctica. The Cryosphere 8: 1105-1119.

Pinzer, B.R., M. Schneebeli, and T.U. Kaempfer. 2012. Vapor flux and recrystallization during dry snow metamorphism under a steady temperature gradient as observed by time-lapse microtomography. Cryosphere 6: 1141-1155.

Popova, V.V. 2011. The snow storage contribution in major changes of river runoff in the Arctic Ocean drainage basin during the current warming period. Ice and Snow 51: 69-78.

Preece, C., T.V. Callaghan, and G.K. Phoenix. 2012. Impacts of winter icing events on the growth, phenology and physiology of sub-arctic dwarf shrubs. Physiologia Plantarum. doi:10.1111/j. 1399-3054.2012.01640.x.

Proksch, M., H. Löwe, and M. Schneebeli. 2015. Density, specific surface area, and correlation length of snow measured by highresolution penetrometry. Journal of Geophysical Research: Earth Surface 120: 346-362.

Prowse, T.D., and K. Brown. 2010. Hydro-ecological effects of changing Arctic river and lake ice covers: A review. Hydrological Research 41: 454-461.

Prowse, T., K. Alfredsen, S. Beltaos, et al. 2011. Past and future changes in Arctic lake and river ice. Ambio 40: 53-62.

Qian, Y., T.J. Yasunari, S.J. Doherty, et al. 2015. Light-absorbing particles in snow and ice: Measurement and modeling of climatic and hydrological impact. Advances in Atmospheric Sciences 32: 64-91.

Qiu, J. 2014. Avalanche hotspot revealed. Nature 509: 142-143.

Qu, X., and A. Hall. 2014. On the persistent spread in snow-albedo feedback. Climate Dynamics 42: 69-81.

Rautio, M., H. Mariash, and L. Forsström. 2011. Seasonal shifts between autochthonous and allochthonous carbon contributions to zooplankton diets in a subarctic lake. Limnology and Oceanography 56: 1513-1524.

Reiweger, I., K. Mayer, K. Steiner, J. Dual, and J. Schweizer. 2015. Measuring and localizing acoustic emission events in snow prior to fracture. Cold Regions Science and Technology 110: 160-169.

Rennert, K.J., G. Roe, J. Putkonen, and C.M. Bitz. 2009. Soil thermal and ecological impacts of rain on snow events in the circumpolar Arctic. Journal of Climate 22: 2302-2315.

Riehm, M., and L. Nordin. 2012. Optimization of winter road maintenance energy costs in Sweden: A critique of site specific frost warning techniques. Meteorological Applications 19: 443-453.

Riseth, J.A., H. Tømmervik, E. Helander-Renvall, et al. 2011. Sámi traditional ecological knowledge as a guide to science: Snow, ice and reindeer pasture facing climate change. Polar Record 47: 202-217.

Rouse, W.R., P.D. Blanken, C.R. Duguay, C.J. Oswald, and W.M. Schertzer. 2008. Climate lake interactions. In Cold region atmospheric and hydrologic studies: The Mackenzie GEWEX experience, vol. 2, ed. M.K. Woo, 139-160. Berlin: Springer.

Roy, A., G. Picard, A. Royer, et al. 2013. Brightness temperature simulations of the Canadian seasonal snowpack driven by measurements of the snow specific surface area. IEEE Transactions on Geoscience and Remote Sensing 51: 4692-4704.

Rumpf, S.B., P.R. Semenchuk, S. Dullinger, and E.J. Cooper. 2014. Idiosyncratic responses of high Arctic plants to changing snow regimes. PLOS ONE 9: 10.

Saloranta, T.M. 2012. Simulating snow maps for Norway: Description and statistical evaluation of the seNorge snow model. The Cryosphere 6: 1323-1337.
Schmid, L., A. Heilig, C. Mitterer, J. Schweizer, H. Maurer, R. Okorn, and O. Eisen. 2014. Continuous snowpack monitoring using upward-looking ground-penetrating radar technology. Journal of Glaciology 60: 509-525.

Schmidt, N.M., R.A. Ims, T.T. Høye, et al. 2012. Response of an arctic predator guild to collapsing lemming cycles. Proceedings of the Royal Society B-Biological Sciences 279: 4417-4422.

Schneebeli, M., and J.B. Johnson. 1998. A constant-speed penetrometer for high-resolution snow stratigraphy. Annals of Glaciology 26: $107-111$.

Screen, J.A. 2014. Arctic amplification decreases temperature variance in northern mid- to high-latitudes. Nature Climate Change 4: $577-582$.

Screen, J.A., and I. Simmonds. 2012. Declining summer snowfall in the Arctic: Causes, impacts and feedbacks. Climate Dynamics 38: 2243-2256.

Semenchuk, P.R., B. Elberling, and E.J. Cooper. 2013. Snow cover and extreme winter warming events control flower abundance of some, but not all species in high arctic Svalbard. Ecology and Evolution 3: 2586-2599.

Semenov, V.A. 2013. Climate-related change of snow contribution in the development of dangerous hydrological phenomena on rivers. Ice and Snow 53: 107-112.

Semmens, K.A., J. Ramage, A. Bartsch, and G.E. Liston. 2013. Early snowmelt events: Detection, distribution, and significance in a major sub-arctic watershed. Environmental Research Letters 8: 11.

Serreze, M.C., and R.G. Barry. 2011. Processes and impacts of Arctic amplification: A research synthesis. Global and Planetary Change 77: 85-96.

Shen, F.X., and M.S. Yao. 2013. Are we biologically safe with snow precipitation? A case study in Beijing. PLOS ONE 8: 11.

Shnyparkov, A., S. Fuchs, S. Sokratov, K. Koltermann, Y.G. Seliverstov, and M. Vikulina. 2012. Theory and practice of individual snow avalanche risk assessment in the Russian Arctic. Geography, Environment, Sustainability 5: 64-81.

Sihvola, A., and M. Tiuri. 1986. Snow fork for field determination of the density and wetness profiles of a snow pack. IEEE Transactions on Geoscience and Remote Sensing GE-24: 717-721.

Simon, A., M.B. Poulin, A.N. Rousseau, and N.H. Ogden. 2013. Fate and transport of Toxoplasma gondii Oocysts in seasonally snow covered watersheds: A conceptual framework from a melting snowpack to the Canadian Arctic coasts. International Journal of Environmental Research and Public Health 10: 994-1005.

Slater, A.G., and D.M. Lawrence. 2013. Diagnosing present and future permafrost from climate models. Journal of Climate 26: 5608-5623.

Sosnovsky, A.V., P.R. Nakalov, and S.V. Nenashev. 2014. Physicalgeographical aspects of formation of artificial firn-ice massives. Ice and Snow 54: 113-119.

Stacheder, M. 2005. TDR and low-frequency measurements for continuous monitoring of moisture and density in a snow pack. International Agrophysics 19: 75-78.

Steffen, K., S.V. Nghiem, R. Huff, and G. Neumann. 2004. The melt anomaly of 2002 on the Greenland Ice Sheet from active and passive microwave satellite observations. Geophysical Research Letters. doi:10.1029/2004GL020444.

Stien, A., R.A. Ims, S.D. Albon, et al. 2012. Congruent responses to weather variability in high arctic herbivores. Biology Letters 8: 1002-1005.

Sturm, M., J.A. Maslanik, D.K. Perovich, J.C. Stroeve, J. RichterMenge, T. Markus, J. Holmgren, J.F. Heinrichs, and K. Tape. 2006. Snow depth and ice thickness measurements from the Beaufort and Chukchi seas collected during the AMSR-Ice03 
campaign. IEEE Transactions on Geoscience and Remote Sensing 44: 3009-3020.

Surdu, C.M., C.R. Duguay, L.C. Brown, and D. Fernández Prieto. 2014. Response of ice cover on shallow lakes of the North Slope of Alaska to contemporary climate conditions (1950-2011): Radar remote-sensing and numerical modeling data analysis. The Cryosphere 8: 167-180.

Takala, M., K. Luojus, J. Pulliainen, et al. 2011. Estimating northern hemisphere snow water equivalent for climate research through assimilation of space-borne radiometer data and ground-based measurements. Remote Sensing of Environment 115: 3517-3529.

Tang, Q., X. Zhang, X. Yang, and J.A. Francis. 2013. Cold winter extremes in northern continents linked to Arctic sea ice loss. Environmental Research Letters 8: 014036.

Tedesco, M., X. Fettweis, T. Mote, J. Wahr, P. Alexander, J.E. Box, and B. Wouters. 2013. Evidence and analysis of 2012 Greenland records from spaceborne observations, a regional climate model and reanalysis data. Cryosphere 7: 615-630.

Terzago, S., J. von Hardenberg, E. Palazzi, and A. Provenzale. 2014. Snowpack changes in the Hindu Kush-Karakoram-Himalaya from CMIP5 global climate models. Journal of Hydrometeorology 15: 2293-2313.

Thackeray, C.W., C.G. Fletcher, and C. Derksen. 2014. The influence of canopy snow parameterizations on snow albedo feedback in boreal forest regions. Journal of Geophysical Research: Atmospheres 119: 9810-9821.

Urban, M., M. Forkel, J. Eberle, C. Huettich, C. Schmullius, and M. Herold. 2014. Pan-Arctic climate and land cover trends derived from multi-variate and multi-scale analyses (1981-2012). Remote Sensing 6: 2296-2316.

Van Den Broeke, M., C. Bus, J. Ettema, and P. Smeets. 2010. Temperature thresholds for degree-day modelling of Greenland ice sheet melt rates. Geophysical Research Letters 37: L18501.

Van Herwijnen, A., and J. Schweizer. 2011. Seismic sensor array for monitoring an avalanche start zone: Design, deployment and preliminary results. Journal of Glaciology 57: 267-276.

Vikhamar-Schuler, D., I. Hanssen-Bauer, T.V. Schuler, S.D. Mathiesen, and M. Lehning. 2013. Use of a multilayer snow model to assess grazing conditions for reindeer. Annals of Glaciology 54: 214-226.

Vionnet, V., E. Brun, S. Morin, et al. 2012. The detailed snowpack scheme Crocus and its implementation in SURFEX v7.2. Geoscientific Model Development 5: 773-791.

Walsh, J.E. 2014. Intensified warming of the Arctic: Causes and impacts on middle latitudes. Global and Planetary Change 117: 52-63.

Webster, M.A., I.G. Rigor, S.V. Nghiem, N.T. Kurtz, S.L. Farrell, D.K. Perovich, and M. Sturm. 2014. Interdecadal changes in snow depth on Arctic sea ice. Journal of Geophysical ResearchOceans 119: 5395-5406.

Wever, N., C. Fierz, C. Mitterer, H. Hirashima, and M. Lehning. 2014. Solving Richards Equation for snow improves snowpack meltwater runoff estimations in detailed multi-layer snowpack model. The Cryosphere 8: 257-274.

Wilson, R.R., A. Bartsch, K. Joly, J.H. Reynolds, A. Orlando, and W.M. Loya. 2013. Frequency, timing, extent, and size of winter thaw-refreeze events in Alaska 2001-2008 detected by remotely sensed microwave backscatter data. Polar Biology 36: 419-426.

\section{AUTHOR BIOGRAPHIES}

Stef Bokhorst $(\bowtie)$ is a Post-Doctoral Researcher at the VU University Amsterdam, Netherlands and at NINA in Tromsø. His research interests include the above and belowground response of Polar ecosystems to climate change, having great interest in the changes in winter climate and the impacts of extreme weather events for dwarf shrubs, soil arthropods, and decomposition.

Address: FRAM - High North Research Centre on Climate and the Environment, Norwegian Institute for Nature Research (NINA), PO Box 6606, Langnes 9296, Troms $\varnothing$, Norway.

Address: Department of Ecological Sciences, Vrije Universiteit Amsterdam, De Boelelaan 1085, 1081 HV Amsterdam, The Netherlands.

e-mail: stefbokhorst@hotmail.com; s.f.bokhorst@vu.nl

Stine Højlund Pedersen is a $\mathrm{PhD}$ candidate at Aarhus University as part of the Greenland Ecosystem Monitoring program. Her research interest lies in snow-ecosystem interactions across multiple temporal and spatial scales using a mix of observations and models.

Address: Department of Bioscience, Arctic Research Centre, Aarhus University, Frederiksborgvej 399, 4000 Roskilde, Denmark.

e-mail: shp@bios.au.dk

Ludovic Brucker received his Ph.D. degree in Earth System Sciences from the University of Grenoble/Centre National de la Recherche Scientifique, Grenoble, France, in 2009. Since then, he has been with the NASA Goddard Space Flight Center, Greenbelt, MD, USA. He has participated in polar deployments in Antarctica, Greenland, and northern Canada. His research interests include the investigation of climate evolution in polar regions by interpreting spaceborne microwave observations of snow-covered surfaces (terrestrial snowpacks, sea ice, and ice sheet), the comprehension of the relationships between passive microwave airborne and spaceborne observations and snow/ice physical properties using modelling approaches to provide climate-related variables to the community for the satellite era.

Address: NASA GSFC Cryospheric Sciences Laboratory, Code 615, Greenbelt, MD 20771, USA.

Address: Goddard Earth Sciences Technology and Research Studies and Investigations, Universities Space Research Association, Columbia, MD 21044, USA.

e-mail: ludovic.brucker@nasa.gov

Oleg Anisimov is a Professor of Physical Geography at the Hydrological Institute in St. Petersburg, Russia, the coordinating lead author of the Polar regions chapters in the Third, Fourth and Fifth IPCC reports and the lead author of the international scientific assessments focused on the Arctic (ACIA, SWIPA).

Address: State Hydrological Institute of Roshydromet, 23 Second Line V.O., St.Petersburg, Russia 199053.

Address: International Centre for Science and Education "Best", North-East Federal University, Yakutsk, Russia.

e-mail: oleg@oa7661.spb.edu

Jarle W. Bjerke is a Senior Researcher at the Norwegian Institute for Nature Research. His research interests include the impacts of climate change and land use on vegetation and terrestrial ecosystems of cold biomes.

Address: FRAM - High North Research Centre on Climate and the Environment, Norwegian Institute for Nature Research (NINA), PO Box 6606, Langnes 9296, Troms $\varnothing$, Norway.

e-mail: jarle.werner.bjerke@nina.no

Ross D. Brown is a Research Scientist with the Climate Research Division of Environment Canada located at the Ouranos Climate Consortium in Montreal, Canada. His research interests include documenting and understanding snow-cover variability and change, the representation of snow processes in climate and hydrological models and the validation of snow cover in regional and global climate models. 
Address: Climate Research Division, Environment Canada Ouranos, 550 Sherbrooke St. West, 19th Floor, Montreal, QC H3A 1B9, Canada. e-mail: ross.brown@ec.gc.ca

Dorothee Ehrich is an Arctic Ecologist and her research focuses on food web interactions in the Arctic tundra, ecosystem monitoring in the context of climate change, and natural resource use in Arctic terrestrial ecosystems. Her experience includes field work mostly in Russia, but also in Canada, northern Norway, and Svalbard, as well as the use of molecular ecological methods such as genetics and stable isotopes. She works also on developing a collaborative monitoring programme for the tundra ecosystem between northern Norway and several sites in Russia.

Address: Department of Arctic and Marine Biology, University of Troms $\varnothing, 9037$ Troms $\emptyset$, Norway.

e-mail: dorothee.ehrich@uit.no

Richard L. H. Essery is a Reader in the School of GeoSciences at the University of Edinburgh with research interests in modelling and observation of land-atmosphere interactions in cold regions.

Address: School of GeoSciences, University of Edinburgh, Edinburgh, UK.

e-mail: richard.essery@ed.ac.uk

Achim Heilig received a Diploma in Physical Geography from LMU Munich in 2005 and the Dr. rer. nat. in Environmental Physics in 2009 from the University of Heidelberg, Germany. He is currently pursuing Postdoc at WSL in Davos, Switzerland, and LMU Munich. He has also used electromagnetic wave technologies to non-destructively record temporal changes in snow, firn and ice in alpine and polar regions. Address: Institute of Environmental Physics, University of Heidelberg, Im Neuenheimer Feld 229, 69120 Heidelberg, Germany.

e-mail: achim.heilig@wsl.ch

Susanne Ingvander received her $\mathrm{PhD}$ in 2011 from Stockholm University. Her $\mathrm{PhD}$ focused on ground truth validation of surface snow conditions at the Antarctic plateau. She is currently leading a research project funded by the Swedish National Space Board studying spatial and temporal variability of the snow pack in the Swedish mountain range using remote sensing.

Address: Department of Physical Geography, Stockholm University, 10691 Stockholm, Sweden.

e-mail: susanne.ingvander@natgeo.su.se

Cecilia Johansson is a Senior Lecturer in Meteorology at the Department of Earth Sciences, Uppsala University, Sweden. Her research interest includes boundary layer meteorology, climatology and snow physics.

Address: Department of Earth Sciences, Uppsala University, Villavägen 16,75236 Uppsala, Sweden.

e-mail: cecilia.johansson@met.uu.se

Margareta Johansson is a Researcher at the Department of Earth and Ecosystem Sciences, Lund University and at the Royal Swedish Academy of Sciences, Stockholm, Sweden. She has specialized in permafrost dynamics in relation to climate change and its impact on ecosystems.

Address: Department of Physical Geography and Ecosystem Science, Lund University, Sölvegatan 12, 22362 Lund, Sweden.

Address: Royal Swedish Academy of Sciences, PO Box 50005, 104 05 Stockholm, Sweden.

e-mail: margareta.johansson@nateko.lu.se

Ingibjörg Svala Jónsdóttir is a Professor in Ecology at the University Centre in Svalbard and the University of Iceland. Her research interests focus on impact of climate change on plants and ecosystems and plant-herbivore interactions.

Address: University Centre in Svalbard, PO Box 156, 9171 Longyearbyen, Norway.

Address: Faculty of Life- and Environmental Sciences, University of Iceland, Sturlugata 7, 101 Reykjavík, Iceland.

e-mail: isj@hi.is

Niila Inga is Reindeer Herder and Chair of Laevas Sami community, northern Sweden. He is engaged in several research projects dealing with the effect of climate and land-use change on reindeer husbandry. Address: Leavas Sámi Community, Box 53, 98121 Kiruna, Sweden. e-mail: niila@laevas.se

Kari Luojus is a Senior Research Scientist at the Arctic Research Division of Finnish Meteorological Institute in Helsinki, Finland. His research interests include the development of active and passive microwave remote sensing techniques for cryosphere and in particular snow-cover monitoring. He has worked on several international projects on satellite snow remote sensing and also worked as the project manager for the ESA GlobSnow-1/2 projects between 2008 and 2014, which focused on constructing long-term essential climate variables concerning terrestrial snow cover.

Address: Arctic Research, Finnish Meteorological Institute, P.O. Box 503, 00101 Helsinki, Finland.

e-mail: kari.luojus@fmi.fi

Giovanni Macelloni is a Senior Scientist at IFAC-CNR, Florence. His main research interest includes microwave active and passive remote sensing for the study of the cryosphere using data from ground, airborne and satellite. He has been the leader of several national and international programmes granted by the National and International and Entities (PNRA, ESA, ASI, NASA and NASDA) and has also participated in the development and assessment of future spaceborne missions for studying the cryosphere.

Address: IFAC-CNR - Institute of Applied Physics "Nello Carrara", National Research Council, Via Madonna del Piano 10, 50019 Sesto Fiorentino, FI, Italy.

e-mail: g.macelloni@ifac.cnr.it

Heather Mariash is an Aquatic Biologist with a focus on Arctic inland waters, specializing in water chemistry, food web dynamics and using biochemical-tracing techniques. She holds a Garfield Weston Post-Doctoral Fellowship for Northern Studies, and is active in the Association for Polar Early Career Scientists (APECS).

Address: National Wildlife Research Centre, Environment Canada, 1125 Colonel By Drive, Ottawa K1A 0H3, Canada.

e-mail: heather.mariash@gmail.com

Donald McLennan is the Head of Monitoring Science at the Canadian High Arctic Research Station-Polar Knowledge Canada in Cambridge Bay, Nunavut. He has been directly involved in arctic ecosystem monitoring and mapping, both in his recent position at CHARS, and for 12 years as Head of Ecological Integrity Monitoring for Canada's National Park system. His background as an applied scientist is in the mapping, monitoring and interpretation of landscape scale pattern and process for scientific and land management applications.

Address: Canadian High Arctic Research Station (CHARS), 360 Albert Street, Suite 1710, Ottawa, ON K1R 7X7, Canada. e-mail: donald.mclennan@polar.gc.ca

Gunhild Ninis Rosqvist is a Professor in Geography at Stockholm University, Sweden, Professor II at University of Bergen, Norway, and the Director of Tarfala Research Station, northern Sweden. She has established links between cross-disciplinary science and Sami 
knowledge to develop research focusing on the effect of multiple and cumulative impacts of climate and land-use change on mountain ecosystems.

Address: Department of Physical Geography, Stockholm University, 106 91 Stockholm, Sweden.

Address: Department of Earth Sciences, University of Bergen, 5020 Bergen, Norway.

e-mail: gunhild.rosqvist@natgeo.su.se

Atsushi Sato is a senior expert researcher at the Snow and ice Research Center of the National Research Institute for Earch Science and Disaster Prevention. His interests include physical snow characteristics and their impact on avalanche risk.

Address: Snow and Ice Research Center, National Research Institute for Earth Science and Disaster Prevention, 187-16 Suyoshi, Nagaoka, Niigata 940-0821, Japan.

e-mail: asato@bosai.go.jp

Hannele Savela completed her $\mathrm{PhD}$ in Physiological Zoology from the University of Oulu, Finland, in 2005. Her research focused on experimental and field studies in applied animal physiology of one of the most iconic Arctic animals - the reindeer. She is currently working at Thule Institute in the University of Oulu as the Transnational Access Coordinator of INTERACT (International Network for Terrestrial Research and Monitoring in the Arctic) and as the Research Area Coordinator for the University of the Arctic. She is one of the co-leads in the Group on Earth Observations (GEO) Cold Regions Initiative.

Address: Thule Insitute, University of Oulu, PO Box 7300, 90014 Oulu, Finland.

e-mail: hannele.savela@oulu.fi

Martin Schneebeli received his Dipl.Ing. and Dr.Sc. degrees in Environmental Engineering from ETH Zurich, Switzerland, in 1984 and 1991, respectively. He is currently a Group Leader of snow physics at WSL and lecturer at ETH Zurich. He developed several new methods to measure the microstructure and stratigraphy of snow quantitatively in the field and in the laboratory.

Address: WSL Institute for Snow and Avalanche Research SLF, Flüelastrasse 11, 7260 Davos Dorf, Switzerland.

e-mail: martin.schneebeli@wsl.ch

Aleksandr Sokolov defend his $\mathrm{PhD}$ thesis in 2003 on small rodents and birds of prey interactions. Since 1999, he has been leading a field group at Tundra monitoring site "Erkuta" in southern Yamal, where ecosystembased monitoring of different groups of organisms was conducted on year-round basis. He has also led the expeditions to remote areas of Yamal, Taymir, Lena Delta and Kolyma Delta. He has been the leader of Yamal group of researchers at IPY projects "Arctic predators" and "Arctic WOLVES" and also an active participant of International World Working Group on Snowy Owl. He has also been the station manager of Labytnangi Research Station in the project "INTERACT".

Address: Arctic Research Station of Institute of Plant and Animal Ecology, Ural Branch, Russian Academy of Sciences, Labytnangi, Russia 629400.

Address: Science Center for Arctic Studies, State Organization of YamalNenets Autonomous District, Salekhard, Russia.

e-mail: sokhol@yandex.ru

Sergey A. Sokratov is senior research scientist in Natural Risks Assessment Laboratory and in the Research Laboratory of Snow Avalanches and Debris Flows, Faculty of Geography, Lomonosov Moscow State University. His interests include mass and energy balance of the snow cover, physical processes in snow and the quantification of snow-related natural hazards.

Address: Arctic Environment Laboratory, Faculty of Geography, M.V. Lomonosov Moscow State University, Leninskie gory 1, Moscow, Russia 119991.

e-mail: sokratov@geol.msu.ru

Silvia Terzago is a Post-Doctoral researcher at the Institute of Atmospheric Sciences and Climate of the Italian National Research Council in Torino. Her expertise is on climate variability and change in high elevation areas, with a focus on snow-related processes. She has worked on the representation of snowpack dynamics in landsurface models and on the assessment of the models uncertainties when they are used in "stand-alone" configuration or within global climate models.

Address: Institute of Atmospheric Sciences and Climate, National Research Council (ISAC-CNR), Corso Fiume 4, 10133 Turin, Italy. e-mail: s.terzago@isac.cnr.it

Dagrun Vikhamar-Schuler is a Senior Scientist at MET Norway with a $\mathrm{PhD}$ in Geosciences (remote sensing and snow modelling). Her research focuses mainly on analysis of winter climate and snow conditions for various impact studies, namely snow avalanche warning, hydrological applications, geohazards, permafrost, and ecology (impact of snow cover on plants, reindeer, crops). She has been involved in numerous national and international projects dealing with analysis of past, present and future climate. Her specialities are land-surface modelling with emphasis on snow and soil schemes, and Arctic winter climate.

Address: Division for Model and Climate Analysis, R\&D Department, The Norwegian Meteorological Institute, Postboks 43, Blindern, 0313 Oslo, Norway.

e-mail: dagrun@met.no

Scott Williamson is a Post-Doctoral Fellow at the University of Alberta. His research interests include trying to understand how climate and cryosphere influence each other.

Address: Department of Biological Sciences, University of Alberta, CW 405, Biological Sciences Bldg., Edmonton, AB T6G 2E9, Canada.

e-mail:snw@ualberta.ca

Yubao Qiu is an associate researcher at the Institute of Remote Sensing and Digital Earth where he uses remote sensing to quantify changes in snow characteristics.

Address: Institute of Remote Sensing and Digital Earth, Chinese Academic of Science, Beijing 100094, China.

Address: Group on Earth Observations, Cold Regions Initiative, Geneva, Switzerland.

Terry V. Callaghan is a Distinguished Research Professor at the Royal Swedish Academy of Sciences and Professor of Arctic Ecology at Universities of Sheffield, UK and Tomsk, Russia. He has specialized in arctic ecology, and climate and UV-B radiation impacts on arctic ecosystems.

Address: Department of Physical Geography and Ecosystem Science, Lund University, Sölvegatan 12, 22362 Lund, Sweden.

Address: Department of Animal and Plant Sciences, University of Sheffield, Sheffield S10 2TN, UK.

Address: National Research Tomsk Stated University, 36, Lenin Ave., Tomsk, Russia 634050.

e-mail: terry_callaghan@btinternet.com 